\title{
PROPRIEDADE PRIVADA E "CIDADE PÚBLICA" NA ITÁLIA. UM (LONGO) TRAJETO AINDA NÃO- CONCLUÍDO.
}

PRIVATE PROPERTY AND "PUBLIC CITY" IN ITALY. A (LONG AND) STILL UNCOMPLETE PATH.

\author{
Giovanni Allegretti ${ }^{1}$ \\ Enrico Zampetti ${ }^{2}$
}

\section{RESUMO}

Focado no contexto italiano, o artigo trata de um elemento essencial ao Direito da Cidade, garantido pela Constituição de 1948: o princípio da função social da propriedade. Para isso, analisa quais instrumentos urbanísticos tornaram-se centrais na sua efetivação, e quais direção e uso estão tomando, na doutrina e nas experimentações de planejamento urbano. Metodologicamente, explora a doutrina e a jurisprudência, a partir de uma perspectiva histórico-sociológica que pretende ler a complexa e contraditória trajetória desta matéria dentro de um âmbito de transformações políticas marcadas por tentativas, mais ou menos bemsucedidas, de combinar a dimensão privada da propriedade com sua projeção pública. A análise evidencia que não se conseguiu alcançar, na legislação, um equilíbrio entre estas duas dimensões, cuja tensão manteve-se nas ambiguidades que marcam os dois instrumentos (equalização urbana e desapropriação simplificada) hoje mais usados num quadro que pretende ultrapassar as contradições de um planejamento urbano baseado no zoneamento e no uso da desapropriação para fins de utilidade pública. Apostar na hibridização destes instrumentos com outras inovações faz parte do "caminho dialético" de transformação cultural de um país ondea

\footnotetext{
$\overline{1}$ Licenciado em Arquitetura (1996) e Doutorado em Planeamento Urbano, Territorial e Ambiental (2000) pela Universidade do Florença, Itália. Atualmente é investigador sénior do Centro de Estudos Sociais (CES) da Universidade de Coimbra, e faz parte do Núcleo "DECIDe". As suas áreas principais de pesquisa incluem a participação dos cidadãos na gestão das transformações territoriais e nos Orçamentos Participativos municipais (Europa, América Latina, Asia e África), temas sobre os quais tem inúmeras publicações. ORCID iD: https://orcid.org/0000-0001-6234-5168

URL: https://ces.uc.pt/pt/ces/pessoas/investigadoras-es/giovanni-allegretti E-mail: giovanni.allegretti@ces.uc.pt

2 Jurista, professor associado de Direito Administrativo e doutor em Direito Público pela Universidade de Siena. Pesquisador sênior no setor disciplinar c Direito administrativo no Departamento de Ciências Políticas e Internacionais da Universidade de Siena. ORCID iD: https://orcid.org/0000-0003-23634543?lang=en CV: https://www.dispi.unisi.it/it/dipartimento/docenti/professori-ordinari-professoriassociati-e-ricercatori/enrico-zampetti E-mail: enrico.zampetti@unisi.it
} 
efetivação da função social da propriedade passa, sobretudo, pelo poder judiciário e as autoridades locais, alternando momentos de preocupações com o aumento dos problemas socioeconômicos, e outros (prevalentes) marcados por uma renovada atenção às liberdades individuais dos cidadãos.

Palavras-chave (PT): Função social da propriedade; consumo de solo; cidade pública; direito urbanístico; instrumentos legais

\section{ABSTRACT}

Focused on the Italian context, the article deals with an essential element of the Right to the City, guaranteed by the 1948 Constitution: the principle of the social function of property. Thus, it analyses which planning instruments have become central in its implementation, and which direction they are following, in the doctrine as in the experiments of urban planning. Methodologically, it explores doctrine and jurisprudence, from a historical-sociological perspective which intends to read the complex and contradictory trajectory of the topic within the scope of political transformations marked by more or less successful attempts to combine the private dimension of property with its public one. The analysis shows that a balance between these two dimensions was not achieved in the legislation. Thus, their tension permeates the ambiguities of the two main tools (equalization and simplified expropriation) which are most used today in a framework that wants to overcome the contradictions of a zoning-based planning approach and the use of expropriation for purposes of public utility. Betting on the hybridization of these instruments with other innovations is part of the "dialectic path" of cultural transformation in a country where the realization of the social function of property passes, above all, through the judiciary and local authorities, alternating moments of concern with the increase in socioeconomic problems, and others (which look prevalent) marked by renewed attention to the individual liberties.

Keywords (EN): Social function of property; land consumption; public city; urban law; legal tools

\section{Introdução}

A literatura sobre Direito à Cidade, no contexto italiano, é ainda escassa, especialmente no que diz respeito à análise concreta dos instrumentos e das políticas que tem vindo permitir a 
concretização desse direito. De fato, na Itália, o próprio conceito de Direito à Cidade ainda não entrou na linguagem dos especialistas do direito. Ele está mais presente dentre os filósofos, os geógrafos e os urbanistas, enquanto no debate político é substituído por outras referências (como a valorização e defesa dos bens comuns -GARCIA e ALLEGRETTI, 2014). Mas - paradoxalmente - é no âmbito do direito que foram produzidos estudos específicos sobre elementos internacionalmente considerados centrais do Direito à Cidade, como é o caso da "função social da propriedade urbana" e dos instrumentos que tem contribuído para traduzir em ações concretas a proteção deste princípio constitucional. O presente texto pretende apoiar-se nestes estudos de âmbito jurídico, para contextualizar as suas conclusões numa perspetiva histórico-sociológica ${ }^{1}$.

Com este intuito, a primeira seção do artigo (tópico 2) propõe uma visão panorâmica da complexa e problemática trajetória da legislação italiana sobre uso e ordenamento do território. Nomeadamente, destacam-se as tentativas - mais ou menos bem-sucedidas - de combinar a dimensão privada da propriedade com sua projeção pública, claramente prefigurada na Constituição (art. 42), com o uso da fórmula "função social da propriedade". Especial atenção é dada à proposta de reforma do então ministro Sullo, que nunca entrou em vigor devido aos conflitos entre as forças políticas e também dentro do próprio governo da época: ela, em suas intenções, visava alcançar uma mais eficaz coordenação entre construção e urbanização do território, também para garantir a função social da propriedade. Outros exemplos dizem respeito à chamada "lei-ponte" e, mais recentemente, às técnicas de equalização urbana destinadas a definir os usos do território com outras ferramentas, além das tradicionais ligadas ao chamado zoneamento.

$\mathrm{Na}$ segunda seção do artigo (tópico 3), são aprofundadas - de um ponto de vista explicitamente jurídico - duas ferramentas do variado e heterogêneo panorama de instrumentos para a efeitivação da função social da propriedade urbana: a propria equalização, já acima mencionada, e o instituto da "desapropriação simplificada". No conjunto, eles se tornaram centrais no contexto da atual desapropriação, assim como para "remediar" a ocupação ilegítima de área urbana realizada pela administração pública, quando existem razões de interesse comum a serem protegidas. A escolha desses dois institutos jurídicos decorreu do fato de que, melhor do que outros, eles podem exemplificar claramente, no estado atual do sistema, a tensão entre a dimensão pública e privada da propriedade, esculpida na Constituição italiana. Desses dois instrumentos, aprofundam-se alguns aspectos críticos relacionados com a vibrante tensão entre as garantias do direito de propriedade, entendido em sua dimensão privada, e a "cidade pública", entendida por 
nós, e assim abordada neste artigo, como um conjunto de ações de política que - na produçãoreprodução do espaço urbano (CARLOS, 2011; LÉFÈBVRE, 1968) - visam garantir primariamente condições para uma melhor qualidade de vida da comunidade como um todo, e a realização de direitos coletivos (que são parte central do Direito à Cidade), também através da valorização da função social da propriedade urbana.

A conclusão (tópico 4) pretende realçar de que forma a trajetória normativa-política das últimas cinco décadas evidencia várias das razões que tornaram frágil, ambígua e (portanto) substancialmente inadequada a legislação criada para - supostamente - efetivar a função social da propriedade urbana. E ainda, as razões que sublinham a dificuldade da cultura dominante de conciliar as dimensões individuais e coletivas do exercício do direito à propriedade, e apelam a uma necessária reforma da Lei de Base do Urbanismo italiano ${ }^{2}$. Esta Lei - merece ser lembrado completou 75 anos em 2018, tendo ela sido introduzida durante a segunda metade dos vinte anos de regime fascista ${ }^{3}$. Na mesma época, completaram-se 55 anos da rejeição da Proposta de Lei (apresentada pelo parlamentar e ex-ministro Fiorentino Sullo) que procurava inverter a relação de força entre a propriedade privada dos solos urbanos e a gestão territorial, criando um sistema de apropriação pública da valorização da renda produzida por eles. Para marcar os 70 anos de vigencia da lei, em 2013, houve uma vaga de artigos e reflexões publicados na imprensa especializada, o que não se repetiu no aniversario de 2018 - nem mesmo no âmbito da imprensa próxima às forças políticas progressistas. Portanto, consideramos que uma reflexão específica (feita também do ponto de vista jurisprudencial) represente uma contribuição relevante e quase única sobre os instrumentos jurídicos e urbanísticos que a Itália conseguiu disponibilizar para efetivar um dos seus princípios constitucionais que mais podem contribuir para a construção do Direito à Cidade.

\section{As raízes de uma ausência}

\subsection{Um macro-contexto em transformação}

Em 2001, a Itália passou por um importante processo de reforma constitucional que modificiou a relação entre os diferentes níveis de administração do Estado. Dentre as alterações estão as novas competências atribuídas às regiões ${ }^{4}$ em termos de planejamento urbano. Desde 1948 a Itália já tinha 5 regiões com estatuto e autonomias especiais (art. 116 da Constituição), e em 1970 foram criadas outras 15 regiões que passaram gradualmente a ter um papel central na estatuição das regras sobre ordenamento do territorio, determinando assim um crescente 
"federalismo urbanístico" ${ }^{5}$ com resultados frequentemente esquisofrênicos. O princípio da subsidiariedade ${ }^{6}$ que regula esta nova governança multinivel no campo do planejamento urbano, também tem assumido um papel central em outras áreas afins, como as novas formas de regulamentação da paisagem, dos bens comuns e do meio ambiente. Neste quadro, relembrar os dois "aniversários" acima mencionados (os 75 anos da entrada em vigor da Lei de Base do Urbanismo e os 55 da rejeição da proposta de lei Sullo), não constitui uma "comemoração digna de uma loja de antiguidades" (BLEČIČ e CECCHINI, 2013), mas uma oportunidade de conciliar as reflexões de um grande número de atores sociais e acadêmicos que - nos últimos dez anos - vêm trabalhando de modo cada vez mais coordenado sobre a matéria do Direito à Cidade. O ponto de partida destes atores não são apenas as lições do filósofo francês LÉFÈBVRE(1968) e de seus discípulos ativos no debate sociológico, econômico e urbanístico contemporâneo (como David Harvey, Marc Purcell e Edward Soja), mas também sugestões procedentes de lutas sociais e de algumas inovações normativas já aplicadas em países como Brasil, Bolívia, Equador e África do Sul. Consequentemente, o suporte normativo vem de campos muito diversos, que incluem quadros legislativos e regulamentares (de diferentes níveis do Estado, incluindo muitas experimentações municipais) que vão desde o urbanismo ao meio ambiente, passando pela proteção dos bens comuns e pelas normas sobre as propriedes coletivas rurais (que existem desde o período medieval tardio), pelas finanças éticas até a agricultura familiar, e muitas outras referências.

De fato, o tema da reivindicação do Direito à Cidade tem, na Itália, variações específicas em relação a outros países (GARCIA e ALLEGRETTI, 2014, p. 70), que estão ligadas especialmente à afirmação da defesa e valorização dos "bens comuns" e das formas ligadas ao comércio justo, à economia solidária e ao tema da desaceleração do decrescimento econômico ${ }^{7}$. Nessa perspetiva, a reforma do modelo de gestão territorial e da propriedade do solo urbano foi ocupando um espaço crescente, sobretudo pelo trabalho de um grupo de urbanistas, economistas e geográfos ligados à "Società dei Territorialisti" (e à Escola Territorialista florentina, que teve um grande papel na sua fundação). Fundamental, também, foi o papel desempenhado pelo portal de informações e discussão chamado "Eddyburg.it”, fundado pelo urbanista EdoardoSalzano, recentemente falecido. Este portal, na década a seguir ao Fórum Social Europeu de Florença (2002), promoveu uma importante série de propostas de reforma normativa relativas à gestão territoral e à paisagem, assim como a tradução e divulgação na Itália dos texos de autores estrangeiros sobre o Direito à Cidade. Muitos dos principais colaboradores atuais do site "Eddyburg.it" estão entre aqueles que divulgaram, em âmbito nacional, a "Carta pelo Direito à Cidade", elaborada por vários movimentos 
sociais durante as edições do Fórum Social de Porto Alegre de 2002, 2003 e 2005, e revista no Fórum das Américas e em numerosos outros encontros internacionais entre organizações e movimentos sociais para uma globalização diferente.

Estes compromissos mais recentes encontraram convergência com várias reinvidicações sociais - sobretudo àquelas pelo Direito à Moradia - conduzidas por movimentos e organizações sociais italianas ligadas à União dos Inquilinos, ao Movimento de Luta pela Moradia, ou a redes internacionais como Habitat International Cohalition (HIC), International Alliance of Inhabitants (IAI) ou No-Vox. As campanhas e as lutas sociais promovidas por estas organizações tendem a ser cada vez mais interligadas e articuladas com plataformas transnacionais que trabalham sobre o tema do Direito à Cidade e, sobretudo, com a Plataforma Global pelo Direito à Cidade (PGDC ou GPRC), que tem sua base no Brasil. O objetivo é construir "massa crítica", não apenas na esperança de contribuir com o reconhecimento jurídico formal, em cada país, do Direito à Cidade (entendido como "direito guarda-chuva" que abriga uma série de direitos humanos já consagrados em Tratados e Declarações Internacionais, e ainda direitos de caráter coletivo), mas também pretende uma maior consagração interna ao sistema das Nações Unidas. Neste sentido, o ano de 2016 foi importante, pois em outubro, na cidade de Quito, Equador, ocorreu a Conferência das Nações Unidas sobre Habitação e Desenvolvimento Urbano Sustentável (conhecida como Habitat III), com agenda parcialmente construída em eventos preparatórios realizados nos anos de 2014 e 2015. Neste evento foram consolidas algumas conquistas sobre as quais vários países trabalharam anteriormente, em especial desde 2010 (quando o V Fórum Urbano Mundial da ONU-Habitat no Rio de Janeiro foi dedicado ao tema "O direito à cidade: unindo o urbano dividido"); e a própria linguagem do debate político e normativo italiano tem gradualmente mudado, incorporando pela primeira vez referências ao Direito à Cidade de forma mais explícita.

Diante desses debates, não há dúvidas de que algumas questões não resolvidas na recente reforma constitucional de 2001 tornaram-se ponto central da reflexão sobre o Direito à Cidade, e alguns protagonistas da história institucional italiana (como o então ministro do partido democratacristão Fiorentino Sullo - ver tópico 2.3) passaram a ser importantes referências simbólicas no atual debate sobre o tema e alguns dos seus corolários, como os instrumentos urbanísticos capazes de tornar mais visível, efetiva e exigível a função social da cidade e da propriedade.

\subsection{Da invisibilidade da administração à inação em torno de reformas estruturais}


Analisar a história do modelo administrativo italiano requer um percurso que vai além da mera "dimensão organizacional" (ou seja, a administração "como sujeito"), das "formas de atividades, dos controles e de tutela", para ligá-la com "a história constitucional de maneira mais direta" (ALLEGRETTI, 2009, p. 116).

De fato, apenas tal perspectiva revela que, na fase de fundação do segundo período do pósguerra, a Itália não se caracterizou por reformas práticas profundas da administração pública, capazes de dar-Ihe "tarefas orgânicas de intervenção social e reestruturá-la em relação à estas" (idem, p. 117). De fato, a Itália reservou ao governo a maior parte da legislação ordinária, subtraindo-a da Constituinte, diferente daquilo que aconteceu na Inglaterra ou na França. Isso pode ser considerado como a origem de um domínio temporário das ideias liberais que impediram (também graças ao pretexto antifascista) algumas reformas estruturais necessárias, e talvez possíveis, no período de transição democrática (TELÒ, 1996).

Como bem demonstrado por RUGGE (1995), na Itália pode-se falar de uma verdadeira "invisibilidade da administração", no debate constituinte como nas décadas que seguiram. Esta invisibilidade foi determinada por um certo "isolamento da história administrativa não apenas em relação à história constitucional, mas também a respeito da história política, econômica e social" (ALLEGRETTI, 2009, p. 119). Neste sentido, para descrever a coerência e os nexos com questões sociais centrais poderiam ser usados termos profundos como "modelo político social aquisitivo/consumista" e "incentivo desigual" que DE FELICE (2003) escolheu para compreender, numa perspectiva histórica, a questão contemporânea italiana e suas ligações com tendências políticas que se concentraram essencialmente "no apoio preferencial de setores de trabalho precário como o artesanato ou a pequena indústria e o pequeno comércio" em estreita conexão com o o setor da construção e a defesa da classe média (ALLEGRETTI, 2009, p. 120). Assim, a gradual reforma da administração pública (entendida como um instrumento ao qual a mesma Constituição atribuiu funções para realizar direitos e deveres sociais e institucionais) raramente obedeceu a uma concepção global. Ao contrário, tendeu a limitar a sua evolução a uma "busca frenética" pela modernização (ALLEGRETTI, 2009, p. 121), que resultou mais visível no campo retórico/discursivo do que nas ações políticas concretas.

Deve-se admitir que o papel mais importante nas transformações da administração pública foi do Tribunal Constitucional (TC), que "sobre o campo das liberdades deu o melhor de si, aparando a legislação pré-constitucional e gradualmente decidindo de forma similar sobre novas leis, não sem alguns acordos com a velha ordem" (ALLEGRETTI, 2014, p. 152). O TC soube também fazer 
avançar, dentro dos limites reduzidos que the são concedidos, os direitos sociais, em particular em nome do princípio da igualdade que têm sido afirmados acima de tudo "através do controle sobre a razoabilidade das leis" (idem, p. 153). Contudo, parece não ter sido capaz de incentivar suficientemente a intervenção das instituições legislativas em âmbitos estratégicos como o da propriedade e do uso do solo. Neste âmbito, a falta de reformas normativas impediu que se desse ao tema um papel organizacional do "setor" do ordenamento urbano e territorial. Ao contrário, a ausência de reformulações tornou-se "ponto de convergência do mecanismo aquisitivo" (ALLEGRETTI, 2009, p. 120), tendo efeitos de percepção negativos sobre a destruição da paisagem e do meio ambiente. Sobretudo, influiu sobre a modificação das áreas litorâneas, que acabaram por configurar-se como alvo de um ataque a importantes direitos e interesses coletivos (SETTIS, 2002). Isso ocorreu, principalmente, através da "concessão das praias" aos estabelecimentos balneares, que beneficiou (e ainda beneficia) atores monopolistas do setor privado, configurandose como uma forma de semi-privatização que (pelos ajustes pouco menos do que "simbólicos" dos preços das concessões nas últimas cinco décadas) não produz qualquer vantagem para a coletividade.

Neste contexto, ocorreram fases alternadas de "idas e vindas" na tentativa de tornar mais "leve" o funcionamento e a burocratização da administração pública, alinhada ao desejo de dar forma a um horizonte inspirado no Estado mínimo. O sistema administrativo tornou-se mais "aberto e multifacetado" (MANNORI e SORDI, 2004), especialmente com as diferenciações devidas ao federalismo regional; contudo, ele não perdeu seu peso e a sua baixa capacidade de ser "amigável" para os cidadãos. Contudo, quando algo melhorou, tornando o sistema tecnocráticoadministrativo menos pesado, raramente foi em decorrência de alterações e reformas políticas. Com efeito, não se deve esquecer que - a partir dos anos 1960 - um papel importante na gradual transformação de parte das políticas de regulação administrativa da Itália foi desempenhado pelo Poder Judiciário, e principalmente pelos "pretori" 8 (juízes de primeiro grau). Estes, foram submetendo a legislação a uma interpretação "constitucionalmente orientada" das leis que deveria aplicar; e assim contribuíram ativamente para colocar o judiciário como verdadeiro "poder de Estado" ao invés de simples "ordem". Ou seja, tornaram o judiciário um "protagonista em muitos conflitos sociais e políticos, às vezes sendo quase responsabilizado em resolvê-los por causa do descumprimento político e legislativo" (ALLEGRETTI, 2014, p. 152). Além disso, não se deve esquecer o papel de alguns administradores locais na implementação de medidas corajosas "constitucionalmente orientadas" - para resolver os problemas de natureza social. Um caso a se 
destacar é o do prefeito de Florença, Giorgio la Pira, que - preocupado com o aumento dos despejos (que tinham subido de 437 em 1950 para 799 em 1951) - não apenas lançou um amplo programa de habitação social (chamado de "casas mínimas"), mas também ordenou a requisição dos imóveis vagos de vários proprietários que se negaram a negociar a sua utilização com a Prefeitura. Para tanto, La Pira recorreu a uma lei de 1865, que atribuía ao Prefeito a possibilidade de requisitar qualquer propriedade privada em situações de emergência ou por motivos de ordem pública.

Apesar destes múltiplos focos de ativismo, a recente historiografia evidencia que muitas das "reformas constitucionais estruturais" (sobre a saúde, a habitação, a educação secundária e universitária) não foram implementadas, em parte por resistências ideológicas no seio da Democracia Cristã que governou a Itália por quase meio século, e em grande parte pelos temores ligados às eleições.

Mesmo com a instituição das regiões nos anos 1970, e a sua reestruturação na reforma constitucional de 2001, infelizmente, a situação não mudou substancialmente. Isto, apesar da retórica que a acompanhou, e apesar do alto desempenho que tiveram algumas regiões, como a Toscana, a Emília Romana e a Basilicata. A estagnação verificou-se por duas razões principais: 1) a inadequação das transferências de competências (que gerou, dentre outras coisas, conflitos levados para o Tribunal Constitucional, que tendeu a decidir em favor do Estado); 2) as restrições gradualmente introduzidas por novas regras financeiras. A nova e imperfeita arquitetura institucional criada com a descentralização regional não foi capaz de incentivar uma transformação substancial da cultura política que se afastasse dos modelos estatais tradicionais. Ao invés disso, houve uma tendência que transformou os entes intermediários em novas "burocracias da vida cotidiana, ${ }^{9}$ não muito bem aceitas pela população e que davam pouco poder às instituições locais menores [especialmente aos municípios]" (ALLEGRETTI, 2014, p. 154). Até, frequentemente, eles foram transformando-se em "novos depósitos para abusos de poder" (GINSBORG, 1989, p. 443).

Deve-se enfatizar que, nessa situação, mesmo as previsões relacionadas à participação dos cidadãos não foram suficientes para dar um real impulso reformista de natureza estrutural. Por exemplo, as restrições criadas ao uso do referendo (inaplicável em muitos campos da ação estatal, como o financeiro e o internacional) ameaçaram seu significado. Embora inicialmente usado em situações claras e gerais que lhe permitiram bons resultados - pelo menos no âmbito de questões éticas privadas (como o aborto e o divórcio) - o instituto do referendo acabou, sobretudo, por um uso excessivo de forma provocativa por parte de alguns partidos, por ser identificado como um substituto corriqueiro das iniciativas parlamentares, a ponto de perder a sua legitimidade popular. 
Em particular, a elevada ineficácia do referendo mostrou-se quando seu uso foi proposto para repensar o aparato organizacional do Estado (como os serviços públicos locais ou o financiamento partidário). Nestes casos, a simples revogação de artigos da lei, por si só, mostrou-se insuficiente para repensar o funcionamento de um procedimento ou de um órgão político-administrativo.

Até mesmos os referendos confirmatórios sobre as mudanças constitucionais (que, ao contrário dos referendos de revogação não têm um quórum exigido por lei) acabaram várias vezes tornando-se reféns de ações de política partidária, ao invés de apoiar uma forte transversalidade institucional. Muitas das mesmas previsões para fomentar a participação cívica a partir da escala nacional tiveram resultados "irrisórios ou mal-sucedidos" (GINSBORG 1989, p. 155) ou percursos muito lentos e ainda inacabados. É o caso das experiências relacionadas aos órgãos colegiados escolares ou às entidades de descentralização inframunicipal (conhecidas por circunscrições) - ou supramunicipais (como a criação de comunidades em montanhas e associações intermunicipais). Isso aconteceu tanto por causa do fraco enraizamento sociocultural com o qual foram concebidos estes novos órgãos administrativos, quanto pela sujeição que Ihes foi dada com relação ao sistema de partidos políticos, e - ainda - por causa da incapacidade de estabelecer uma ligação destas a uma séria reforma administrativa dos aparatos técnico-burocráticos.

Em essência, "a sujeição da administração pública à política" (absolutamente "não minada pela criação do papel dos dirigentes em 1972") (ALLEGRETTI, 2009 ${ }^{10}$ ) muitas vezes enfraqueceu tanto a inovação no funcionamento burocrático diário do país a partir de dentro, quanto a possibilidade de dar resultados concretos às propostas de movimentos internacionais mais amplos (como o New Public Management). Estes, na Itália, acabaram por passar substancialmente despercebidos, ou produzir apenas efeitos de liberalização para o benefício de monopólios privados (por exemplo, no campo da terceirização de serviços locais) sem gerar os benefícios correspondentes de aliviar a estrutura. Ao contrário, por vezes tiveram efeitos paradoxais de sobrecarregar ulteriormente a organização do Estado em função de algumas reformas pontuais da máquina burocrática que passaram no escrutínio parlamentar.

Vários historiadores e juristas atentos às "ausências" de algumas reformas (urgentes e possíveis) na transformação da relação entre Estado e mercado na Itália ${ }^{11}$ têm levantado hipóteses convincentes sobre os principais elementos de paralisia das "reformas estruturais", propostas em várias etapas também dentro da ala social católica progressista do principal partido italiano (a Democracia Cristã). Dentre os elementos que nos anos seguintes ao primeiro boom econômico do pós-guerra, levaram ao bloqueio das maiores reformas propostas, estão, sem dúvida, a inflação e 
o pânico financeiro (que ameaçavam os pequenos e médios poupadores e investidores, desde sempre os defensores mais convictos da Democracia Cristã), bem como a influência inalterada nos círculos financeiros dos antigos monopólios elétricos (sobreviventes da nacionalização da energia). O perigo de perder a simpatia desses setores foi certamente decisivo no bloqueio de algumas iniciativas importantes do estadista Aldo Moro. Muita da historiografia sobre o governo deste importante protagonista da política italiana (morto dramaticamente nas mãos das Brigadas Vermelhas) têm sublinhado o hábito de colocar "os interesses do partido em primeiro lugar" (GINSBORG, 1989, p. 367) e congelar - de acordo com os jogos eleitorais - reformas indispensáveis. Foi o que aconteceu, por exemplo, em 1963 quando se postergou o estabelecimento das regiões ordinárias (por quase uma década) e com a reforma do planejamento urbano, não mais abordadas na forma completa em que foi proposta, em 1962, pelo ministro Fiorentino Sullo.

\subsection{O naufrágio de uma reforma corajosa}

Este último evento merece ser lembrado em detalhes, não só porque "a maneira como foi sabotado continua a ser uma das páginas mais infelizes da história da República", mas também porque "foi a primeira (e última) tentativa séria de chegar a um acordo sobre os problemas da especulação imobiliária e do desenvolvimento urbano caótico" (GINSBORG, 1989, p. 368), que ainda assombra a Itália contemporânea e cujo fim prematuro pesou enormemente como uma ausência ensurdecedora nas décadas seguintes.

O projeto de lei apresentado pela primeira vez pelo Ministro das Obras Públicas, Fiorentino Sullo, em julho de 1962 (ou seja, menos de um ano antes das eleições de 1963) se referia essencialmente à concessão, aos órgãos locais, do direito de desapropriação generalizada de todos os terrenos urbanizáveis incluídos nos chamados "planos detalhados" (ou PP - Piani Particolareggiati) dos respectivos planos de desenvolvimento urbano (PDDUA, ou PRG - Piani Regolatori Generali). Portanto, o projeto vinculava-se a uma paralela reforma do planejamento que ampliava e fortalecia a obrigação dos municípios de planejar melhor as transformações territoriais por meio de uma série de planos concebidos "em cascata" no marco do planejamento econômico geral e local (DE LUCIA, 2013). Nas projeções da proposta de Sullo, essas mesmas autoridades locais deveriam tomar medidas para realizar as obras de urbanização necessárias (esgotos, redes de água, eletricidade e estradas, etc.) para revender a terra urbanizada para particulares, capitalizando o novo preço (maior do que o original, mas controlado pela mão pública), a fim de pôr fim à especulação imobiliária selvagem e de natureza parasitária sobre as áreas edificáveis, que naqueles 
anos o diretor de cinema Francesco Rosi denunciou na sua (muito criticada) obra-prima "Le mani sulla città" (1963) $)^{12}$. Além disso, a proposta impunha a proibição radical do uso de terrenos vagos em áreas abrangidas pelos PPs durante "o período indefinido entre a adoção dos planos gerais de regulamentação e a aprovação de planos para executá-los" (PALADIN, 2004, p. 183), e renunciava a "todas as formas de colaboração dos proprietários" na implementação dos mesmos planos ${ }^{13}$.

Além disso, a proposta do ex-ministro Sullo previa a separação do direito ao solo (ius soli) do direito à propriedade (ius proprietatis) e do direito de construir (ius construendi), prevendo que aos novos proprietários caberia a posse e propriedade apenas dos edifícios, enquanto a propriedade dos solos permaneceria com os municípios, de modo a permitir a estes real controle sobre seu uso. Um tal modelo - achava Sullo - também tornaria a implementação dos planos diretores mais eficaz, bem como asseguraria o cumprimento de seus objetivos e o interesse público. De fato, não se deve esquecer que a desordem urbana reinou no período do pós-guerra e que, em 1961, apenas 78 Planos Regulatórios Gerais haviam sido aprovados dentre os 700 municípios obrigados a realizar tal instrumento (PALADIN, 2004, p. 183). Como Sullo disse anos depois, a proposta era realista para a época, dado que "o Estado ainda tinha dinheiro para fazer expropriações" e teria sido possível "salvar o destino de algumas grandes cidades" (SULLO, 1964, p. 38), posteriormente devastadas pela especulação imobiliária descontrolada ${ }^{14}$.

A abordagem adotada gerou uma furiosa oposição de alguns setores da opinião pública, convencidos, também como resultado de uma forte campanha da imprensa, de que pretendiam proceder à nacionalização indiscriminada dos solos urbanos ${ }^{15}$. Enquanto estes acusavam Sullo de ter intenções bolcheviques, ele não encontrou nenhum apoio significativo nem mesmo nos partidos de esquerda que poderiam (caso entendessem a medida) defender as razões da proposta de lei.

Paradoxalmente, isso ocorreu exatamente quando os democratas cristãos forçosamente estavam abrindo um diálogo com a esquerda, após o trauma gerado em 1960 pelo breve período do governo Tambroni, com sua busca de alianças nos setores da direita ligados ao antigo regime fascista. Em parte, o silêncio dos partidos socialistas e comunistas sobre a tentativa de reforma proposta por Sullo deveu-se a uma séria incapacidade de compreender a situação socioeconômica do momento e suas alterações estruturais: acima de tudo, a incapacidade de compreender as conseqüências de permitir o estabelecimento de um poderoso "bloco fundiário urbano" que estava substituindo os latifundiários agrícolas que dominaram o país e bloquearam as reformas agrárias nas décadas anteriores (ALLEGRETTI, 2002, p. 33). No processo de marginalização produtiva que os latifúndios sofreram - devido ao desmantelamento mais geral da agricultura como centralidade 
produtiva italiana - os proprietários apostaram em alianças urbanas, cujos riscos não foram minimamente compreendidos pelos partidos e os intelectuais da esquerda, enquanto eram favorecidos pelos partidos de centro-direita.

Nem mesmo a abertura do ministro Sullo para derrubar a distinção entre propriedade e posse da terra (GINSBORG, 1989, p. 368) foi suficiente para salvar uma parte da reforma, defendida publicamente pelo futuro Presidente do Conselho de Ministros, Moro, como uma "iniciativa pessoal" de Sullo não apoiada e nem mesmo consensual dentro do partido ${ }^{16}$. Assim, ela foi arquivada pelo Conselho de Ministros, que nem sequer a discutiu, apesar de já ter sido transmitida ao Conselho Nacional de Economia e Trabalho (PALADIN, 2004, p. 184).

Referido evento, que assinalou o fim da carreira política de Fiorentino Sullo (como ele próprio descreveu no livro "Lo scandalo urbanistico"17, de 1964), segundo alguns analistas, seria razão suficiente "para um balanço fortemente negativo da hegemonia democrático-cristã" (ALLEGRETTI, 2002, p. 33), sobretudo pelas fortes consequências que teve, nas décadas seguintes, sobre a crise da qualidade da vida urbana (como o meio ambiente e a paisagem) em muitos centros da Itália.

\subsection{A longa série de medidas paliativas}

Após o colapso da proposta de Sullo, a oportunidade perdida de uma reforma urbana "estruturada" não voltou a se apresentar novamente, nem mesmo quando os partidos de esquerda (nos cinco anos seguintes) perceberam o erro histórico de avaliação que haviam feito. Na verdade, o novo ministro das Obras Públicas, Pieraccini, nomeado após as eleições de 28 de abril de 1963, tentou preparar uma versão revisada e mais suave da lei de reforma urbana, mas o "setor atrasado" (como referiu anos depois ${ }^{18}$ ) provou ser "muito forte" em "influenciar as orientações da classe econômica e política dominante". O próprio governo Moro (que caíu em junho de 1964 e foi retomado em 1966) argumentou que a crise econômica não permitiu considerar as expropriações como uma opção realista (PARLATO, 1978). A única solução parcial adotada, que buscou uma redistribuição mínima de recursos para o benefício público, foi a criação de um imposto sobre os incrementos no valor dos terrenos urbanizáveis, estabelecido pela Lei no 246, de 5 de fevereiro de 1963.

No final, a "política de adiamento" ou de "imobilidade", atribuída a Moro por muitos historiadores, traduziu-se em um adiamento indefinido da reforma urbana, que posteriormente foi 
incapaz de obter outra coisa senão pequenas semelhanças com as medidas propostas em 1962. Nem mesmo algumas catástrofes que atingiram o país em 1966 (como as inundações de Florença e Veneza e os deslizamentos de terra que fizeram desmoronar alguns edifícios construídos ilegalmente no Vale dos Templos em Agrigento, Sicília) conseguiram convencer os novos governos da urgência de aprovar leis adequadas sobre a proteção dos solos e o planejamento urbano.

No máximo, foi possível aprovar algumas medidas paliativas. Entre elas, a denominada "Lei Ponte" de $1967^{19}$, que estabeleceu que são os proprietários das áreas edificáveis que pagam pelas obras primárias de urbanização ${ }^{20}$, e em parte pelos equipamentos incluídos na denominada urbanização secundária ${ }^{21}$. Dois decretos ministeriais de 1968 acrescentaram aos proprietários novos deveres, estabelecendo os padrões (ou standard) de planejamento urbano, especialmente no que diz respeito à presença de áreas verdes, estacionamentos, áreas de proteção de estradas e ferrovias, número de escolas e equipamentos culturais por habitante, entre outros. Em relação a estas medidas (que padronizavam a 'ratio' dimensional e as relações percentuais entre espaços públicos e áreas construídas, bem como os limites de construção à margem das infraestruturas de transporte), a pressão do bloco dos especuladores fundiários urbanos tomou uma forma diferente, conseguindo postergar de um ano a entrada em vigor da "Lei Ponte". Nesse período, conforme evidenciado por FERRARESI e TOSI (1979) e ROCHAT ET AL. (1980), os pedidos de licenças de construção assumiram dimensões gigantescas e "as estratégias dos especuladores para concluir os pedidos antes do fim do antigo regulamento" (GINSBORG, 1989, p. 379) levaram à liberação de mais de um milhão de permissões de construção. Tais volumes frustraram a maior parte dos objetivos da lei e produziram danos irreparáveis ao regime de solo urbano de muitas cidades, bem como à paisagem natural e construída.

Nessa época, a expansão contínua das despesas das autoridades locais (um dos grandes recursos disponíveis para os partidos manterem o controle eleitoral de muitos territórios), seletivamente centrada em algumas áreas de gasto, justificou várias batalhas de organizações de inquilinos para reduzir os custos dos aluguéis e evitar despejos. Mas a falta de homogeneidade de muitos dos bairros mais vulneráveis em termos socioeconômicos (especialmente devido às fortes ondas migratórias internas do sul para o centro-norte do país) tornou difícil a ação coletiva, especialmente para aqueles que residiam em residências pertencentes ao setor privado.

Quando a mediação política para com os protestos coletivos produziu algo, foi sempre algo “descuidado, não planejado, insuficiente" (GINSBORG 1989, p. 442). É o caso da Reforma da Casa, que se tornou lei em $1971^{22}$ e cuja natureza "mais uma vez demonstrou" que em setores-chave 
como este "a reforma bloqueava-se diante dos interesses consolidados e da burocracia estatal". Isto aconteceu apesar de "as forças que estavam pressionando para que houvesse uma reforma do setor de habitação e planejamento urbano fossem muito mais fortes do que na época de Sullo" (GINSBORG 1989, p. 445) especialmente por causa da forte presença do movimento operário e de um forte movimento de massas, o que significava que os reformistas não estavam mais tão isolados quanto na década anterior.

Sem dúvida, as greves gerais dos sindicatos realizadas em diversas ocasiões desde novembro de 1969, precisamente sobre a questão da habitação, não poderiam ser ignoradas, com suas demandas por um controle dos preços de aluguel e maior investimento em habitação pública. Apesar disso, a lei aprovada em outubro de 1971, com a aceitação dos sindicatos, satisfez parcialmente suas solicitações, transferindo para as autoridades locais um sistema simplificado em comparação com o passado, e que thes permitia fazer as desapropriações das áreas necessárias com compensação ao preço médio das terras agrícolas. Além disso, continuava a ter procedimentos complicados, falhas no controle da aplicação e da qualidade dos projetos implementados. Não é coincidência que, em janeiro de 1974, apenas 42 dos 1.062 bilhões de liras alocadas haviam sido gastas (FERRARESI e TOSI, 1979, p. 567).

Como bem escreveu Paul GINSBORG (1989, p. 390), mais uma vez ficou claro que nenhum dos primeiros-ministros e secretários da Democracia Cristã "repudiaria facilmente um modelo de desenvolvimento urbano semelhante ao de Palermo, mesmo que implicasse corrupção, conluio com a máfia e especulação imobiliária desenfreada". Isto porque "grande demais era a sua utilidade política" - através do controle administrativo do boom da construção - como um mecanismo poderoso para obter consenso em todos os setores da população, em um país onde a pequena propriedade da habitação revelava percentagens muito elevadas.

Nos anos seguintes, a Lei no 10, de 28 de janeiro de 1977, (intitulada "Norme per la edificabilità dei suoli" - "Normas para a edificação dos solos") tentou reforçar algumas medidas anti-especulativas, em uma tentativa de beneficiar os atores públicos. Desta vez, foi a jurisprudência constitucional sobre as expropriações a esclarecer a inadmissibilidade de algumas normas, especialmente com a sentença no 5 , de 1980, e outras decisões posteriores sobre a não legitimidade de reiterações de obrigações urbanísticas sem provisão de indenização. Outra medida paliativa foi introduzida pela Lei 392, de 27 de julho de 1978, criando o chamado "controle de aluguel", ou seja, impondo o valor de aluguel dos imóveis em função de uma (às vezes muito) complexa articulação dos parâmetros e coeficientes previstos pela própria lei. Estes parâmetros 
incluíam o tipo de propriedade (rural, de habitação social, econômicas, civil, de luxo), mas também a quantidade de andares (por exemplo, dependendo da presença ou ausência do elevador), o tamanho da cidade, a região e o estado de conservação da unidade habitacional e de quaisquer partes comuns do edifício.

Esta breve história da fase de ascensão e discussão sobre as reformas estruturais necessárias ao país para ampliar o tratamento das liberdades civis e dos direitos sociais - pelo prisma das principais transformações do arcabouço regulatório do urbanismo - esclarece como, das três formas de conceber as reformas que foram propostas (as corretivas, as estruturais e as minimalistas) foram as minimalistas que triunfaram. Isto aconteceu apesar da pompa das declarações programáticas dos vários governos de centro-esquerda que se sucederam entre 1960 e 1975 (GINSBORG, 1989, p. 380).

O centro do debate público sobre as questões acima referidas, nas décadas seguintes, tendeu a permanecer o da proteção da propriedade privada. Esta foi reforçada pela comparação contínua com a Convenção Europeia para a Proteção dos Direitos Humanos e Liberdades Fundamentais (CEDH) e os seus protocolos adicionais ${ }^{23}$. Mas o crescente debate internacional sobre o Direito à Cidade, acima de tudo na última década, serviu para por nova ênfase no outro polo fulcral da questão, ou seja, a necessidade de implementar medidas para enfatizar a indispensável "função social" da mesma propriedade privada.

A jurisprudência (especialmente a do Tribunal Constitucional), chegou a "conclusões diferentes de tempos em tempos", mas parece não ter ainda alcançado certezas "sobre o equilíbrio real entre proteção à propriedade e exigências de solidariedade, com enormes conseqüências práticas", mantendo "uma grande elasticidade, que permitiu dobrá-la às necessidades contingentes do momento" (MONTARULI, 2008).

Neste contexto, não por acaso,vários movimentos sociais ligados à promoção do Direito à Cidade - conscientes de possíveis questões críticas na relação entre a legislação supranacional e a Carta Fundamental - preferem recorrer à Constituição italiana (considerada "claramente pouco aberta às necessidades de solidariedade", MONTARULI, 2008) em vez da CEDH, dado que para esta última a proteção da propriedade privada é uma prioridade. Em particular, esses defensores da necessidade de transformações que permitam concretizar o Direito à Cidade referem-se ao artigo 41 da Constituição, particularmente à afirmação de que "a iniciativa econômica privada é livre" mas "não pode ocorrer em contraste com a utilidade social ou de uma forma que possa prejudicar a segurança, a liberdade, a dignidade humana" e deve ser "tratada e coordenada para fins sociais". 
Importante referência são também aos artigos 42 , 43 e 44 da mesma Carta Fundamental ${ }^{24}$ que se referem à propriedade de áreas urbanas e rurais, e de empresas de serviços de interesse público. Estas referências assumiram um papel importante nos argumentos dos movimentos sociais e de grupos profissionais que se sentem ligados a batalhas progressistas para alcançar maior justiça socioespacial (o que leva em consideração como o tamanho e a localização das propriedades contribui para o crescimento ou redução dos fenômenos de polarização econômica e social - ver SOJA, 2010).

\section{5. $O$ aparecimento gradual de novas ferramentas de controle dos solos}

Pode-se dizer, com MONTARULI (2008), que as aparentes inconsistências da jurisprudência nos últimos trinta anos fazem parte de um "caminho dialético" de transformação cultural do país, que alterna momentos em que as preocupações dos juízes estão mais centradas no aumento dos problemas socioeconômicos, e outros (atualmente prevalentes), onde se destaca "uma atenção renovada às liberdades individuais", possibilitada por períodos de "maior estabilidade financeira" (LICCIARDELLO, 2004, p. 186). Parece que não se pode dizer o mesmo sobre a ação política que ao legislar - parece, até hoje, ter continuado favorecendo a segunda família de preocupações, centrando sua reflexão sobretudo sobre expropriações isoladas, e menos sobre aquelas resultantes de medidas de reforma econômica ou justiça social, em que um bem privado aparece inserido nas previsões legais de planejamento urbano de caráter geral destinadas à realização de fins de utilidade pública.

Nessa perspectiva, parece compreensível que o debate social dos últimos cinco anos sobre as transformações urbanas/edificações e sua relação com a construção de novos horizontes de direitos e maior justiça social tenha oscilado entre dois pólos centrais. De um lado, encontram-se as reivindicações de movimentos (como os ligados à luta pelo direito à moradia) que visam afetar sobretudo a previsão de novas políticas de investimento público em habitação a custos controlados e subsidiadas, bem como a moderação do valor dos aluguéis e as contribuições para os jovens, trabalhadores precários e grupos sociais vulneráveis (incluindo formas de reajuste negociado de prédios não utilizados e/ou ocupados e a promoção de técnicas de autorrecuperação). Por outro lado, um movimento intelectual está crescendo, fortemente ligado a algumas áreas profissionais (como planejamento urbano e geografia urbana) que centra os seus pedidos para clarificação normativa relativas a alguns instrumentos agora identificados como centrais para alcançar um 
"ponto de equilíbrio" mais adequado entre a protecção dos direitos de propriedade e os requisitos de solidariedade e a promoção dos interesses coletivos dos habitantes de um território.

Em particular, a reflexão deste segundo grupo de reivindicações tem por base, hoje, uma série de instrumentos ligados ao princípio da "equalização urbanística", sobre a qual voltaremos mais plenamente no tópico 3. A centralidade recentemente alcançada por este instituto é o resultado de um princípio de realidade. Ou seja, a proposta aceita o fato de que a crise financeira das instituições administrativas (especialmente das instâncias locais) é demonstrada e dificilmente reversível, especialmente num quadro Europeu, onde a pertença à União Europeia requer o respeito de parâmetros de dívida e de princípios de equilíbrio financeiros de todas as instituições públicas. Isto indica uma objetiva dificuldade de fazer escolhas de planejamento de interesse público através de medidas "coercitivas" contra os proprietários dos solos, especialmente tendo em conta que as desapropriações podem levar a altos custos para a comunidade, o que não pode ser previsto com certeza durante a fase de planejamento devido a flutuações nos valores do mercado de terras. Lida a partir deste ângulo, a equalização urbanística é hoje entendida como uma nova ferramenta potencialmente benéfica para a gestão das transformações urbanas, embora sua aplicação concreta permaneça ancorada em instrumentos preexistentes, enraizados na vocação de equalização (isto é, na capacidade de prever a superação do tratamento desigual) dos "setores de construção" já previstos pelo artigo 23 da Lei de Planejamento Urbano, Lei no 1150, de $1942^{25}$.

De fato, a equalização não está moldada pela previsão completamente nova de um instrumento normativo específico, nem requer a existência de grandes reformas. Ao contrário, ela tem entrado gradualmente na prática urbanística italiana a partir de 1982, ancorando-se em instrumentos preexistentes e completando sua interpretação com a adoção de algumas descontinuidades, em busca principalmente dos benefícios a seguir:

1) gerar uma maior garantia de eficiência na distribuição de recursos e eficácia urbana, graças à associação de um melhor desenho urbano com a concentração do edificado em algumas áreas, enquanto outras (de tamanho significativo) são reservadas para áreas verdes e serviços;

2) permitir a fixação negociada de cessões de áreas e oneração extra, que possam gerar benefícios fiscais, compensando a fracassada reforma legislativa da tributação das mais-valias nas transformações urbanas; 
3) favorecer a aceleração dos empreendimentos, evitando procedimentos de desapropriação por utilidade pública longos e onerosos, bem como transações muito caras entre particulares e dificilmente programáveis nos seus prazos de conclusão;

4) garantir maior equidade no tratamento dos interesses privados, na medida em que gera indiferença das áreas em relação às decisões seletivas dos planos urbanísticos (em termos de localização dos terrenos para construção).

Evidentemente, como apontado por CAMAGNI (2011), o papel de "instrumento útil e salvador em todas as ocasiões e em todas as suas conjugações" gradualmente adquirido pelo instituto nos trinta anos de debate sobre a reforma urbana é um erro de perspectiva. Como o é a "força evocativa do lema, que se refere a cenários mais amplos de justiça distributiva e realocação de riqueza" (TRAINA, 2015) de algo que deve ser visto principalmente - de forma realista - como "uma técnica de planejamento para fins plurais". Esta, ao dissociar os potenciais de construção da concreta transformabilidade do solo, permite atribuir um valor de construção uniforme às propriedades destinadas a usos urbanos (...) independentemente do local em que os edifícios e as infraestruturas públicas relacionadas irão surgir" (TRAINA, 2015, p. 688).

De fato, os potenciais benefícios da equalização supracitada exigem condições precisas de garantia para poder acontecer, e em particular (TRAINA, 2015, p. 688):

a) "que seja acoplado a um planejamento racional e de longo prazo e ao desenho urbano;

b) que seja usado para alcançar igual e equilibrado tratamento de interesses iguais, de fato e de direito, e, portanto, que o índice único de construção seja atribuído a áreas de valor intrínseco similar (em termos de qualidade urbana e ambiental, de acessibilidade) e, portanto, em setores limitados e não em toda a cidade (...);

c) que seja utilizado de forma transparente na negociação entre o público e o privado sobre as modalidades de troca, ou melhor, de permuta entre, de um lado, volumes de edifícios, e de outro, a venda de áreas e outras monetarizações (...);

d) que a negociação entre o público e o privado ocorra nas melhores condições de informação e capacidade contratual por parte do órgão público e, portanto, acima de tudo, através da competição entre diferentes projetos de desenvolvimento nas áreas urbanas mais relevantes".

Conforme veremos na próxima seção, a jurisprudência que acompanhou o uso da equalização urbanística nos últimos trinta anos serviu não tanto para mostrar a solidez ou a 
singularidade das disposições regulatórias que estão em sua base, mas a complexidade do instituto e a necessária articulação entre as diferentes condições que, conjuntamente, estão na base de sua eficácia e legitimidade substancial.

\section{Planejamento e desapropriação nos institutos de equalização urbanística e desapropriação simplificada ${ }^{26}$}

\subsection{Dimensão individual e função social no direito de propriedade}

Para entender melhor as transformações dos instrumentos jurídico-urbanísticos que se criaram e se consolidaram gradualmente no período mais recente, é necessário ressaltar que, no ordenamento jurídico italiano, a proteção da propriedade é garantida pelo artigo 42 da Constituição. Como melhor explicado abaixo, o texto constitucional exige que o exercício da lei tenda a alcançar (também) a chamada "função social", desviando o direito de propriedade da dimensão individualista mais estreita para fortalecer uma interação mais ampla com a dimensão social e coletiva. Em outras palavras, o exercício do direito de propriedade privada deve ser assegurado de tal maneira a garantir também um possível resultado de utilidade social que vai além da utilidade que o proprietário individual pode derivar para si do exercício de seu direito. Embora a restrição da função social não elimine a livre fruição da propriedade, ela constitui a base jurídica para todas as intervenções normativas e administrativas destinadas a limitar ou, em outros casos, até a sacrificar o exercício do direito de assegurar a satisfação de necessidades mais gerais, que pode ser a protecção do ambiente ou patrimônio cultural, ou a criação de espaços e infra-estruturas de interesse coletivo ${ }^{27}$.

Neste terceiro tópico queremos aprofundar a análise, no sistema legal italiano em vigor atualmente, de como o direito de propriedade é objeto de contínua tensão entre a dimensão individual e a dimensão coletiva, visando identificar o equilíbrio entre o exercício do direito pelo proprietário e o cumprimento da função social mais ampla referida no texto constitucional. Para chegar a esse ponto de equilíbrio, o sistema jurídico propõe várias soluções no nível regulatório, ou apenas no nível administrativo. Entre estas, no período mais recente, merece realçar os institutos da chamada "equalização urbanística" e a "desapropriação simplificada", que adquirem particular interesse dado que são uma expressão da tensão que caracteriza o direito de propriedade no sistema legal italiano. Podemos afirmar desde logo que - dentre os instrumentos existentes - a equalização acaba por ser, provavelmente, o mais adequado para conciliar as dimensões pública e 
privada; por outro lado, a chamada "desapropriação simplificada "revelam, por sua vez, mais aspectos críticos, especialmente em termos da comparação desequilibrada (e portanto inadequada) entre os interesses do indivíduo e as necessidades gerais.

\subsection{A equalização urbanística. Um possível ponto de equilíbrio entre lei de propriedade e "cidade} pública"?

Como já antecipado, o artigo 42, parágrafo 2 을 Constituição italiana exige que os métodos de aquisição, gozo e os limites de propriedade devem encontrar disciplina na lei "a fim de assegurar a função social e torná-lo acessível a todos". De acordo com a Constituição, é na lei específica que se deve identificar os limites da propriedade e seu gozo de uma maneira geral e abstrata, enquanto o poder público é encarregado da implementação concreta desses limites.

A reserva legal não exclui a intervenção da administração, mas garante que o poder público a exerça de forma a cumprir requisitos predeterminados, entre os quais assume particular importância o já mencionado conceito da "função social" ${ }^{28}$. Com base neste, a propriedade pode estar sujeita às chamadas restrições "conformativas", que condicionam seus métodos de gozo para proteger interesses gerais. É o caso de restrições paisagísticas ou culturais, ou mesmo das previsões dos instrumentos de planejamento urbano que impõem um destino específico à área, ou um regime de construção específico (altura máxima, volume máximo, standard de relação entre edificado e verde, entre superfícies e fontes de iluminação natural e ventilação, etc. $)^{29}$.

É bem sabido que intervenções conformativas do direito de propriedade tendem a ocorrer principalmente através de instrumentos de planejamento do uso do solo adotados pelas autoridades locais (regulamentos de edificação, normas urbanísticas, planos gerais ou de pormenor etc.). Dentre estes, os planos diretores municipais desempenham um papel principal, que - na tradição italiana herdada da lei nacional no 1150 de 1942 - dividem o solo urbano em zonas territoriais que tendem a ser homogêneas, também independentemente das características relativas de fato, atribuindo a cada uma delas os destinos relativos e o regime predial. Assim (como indicado nas recomendações funcionalistas da Carta de Atenas de 1933), existem zonas industriais, zonas agrícolas, zonas de expansão, zonas para a construção de infra-estruturas e serviços para a comunidade, entre outras.

No entanto, o planejamento de acordo com a técnica de zoneamento provoca inevitável discriminação entre os proprietários, uma vez que as escolhas do plano beneficiam alguns e 
penalizam outros. Basta pensar no caso de proprietários que têm áreas localizadas, respectivamente, em áreas para construção ou destinadas a assegurar espaços coletivos (ou seja, as instalações de infra-estrutura e serviços de interesse público). No primeiro caso, o proprietário terá à sua disposição uma área que, sendo possível construir, tem um valor econômico significativo no mercado; no segundo, a área, por estar ligada à construção de infraestruturas e serviços à comunidade, está destinada a ser expropriada com tudo o que se segue em termos de menor valor econômico e falta de conveniência no mercado imobiliário. Esta situação determina um "desequilíbrio" entre proprietários no que diz respeito ao livre uso da sua propriedade, também (e sobretudo), levando em consideração o fato de que as distintas destinações não são designadas pelas características naturais (por assim dizer) das áreas. O zoneamento revela seus limites também em relação àquela que temos definido como "cidade pública" (sobretudo o conjunto dos espaços verdes, de mobilidade, e de equipamento coletivos), uma vez que nem sempre permite facilmente a criação de espaços coletivos para infraestruturas e serviços. De fato, as áreas destinadas à cidade pública devem ser desapropriadas, e isto expõe o poder público local aos encargos econômicos da compensação constitucionalmente garantida e às possíveis disputas originadas pelos proprietários para impedir o sacrifício do direito pleno à propriedade privada. Não é por acaso que, muitas vezes, a desapropriação não está concluída, tanto pela impossibilidade de o poder público local enfrentar o peso econômico relativo, como pela lentidão e obstáculos que podem caracterizar o processo de desapropriação.

A desigualdade entre os proprietários e a dificuldade de adquirir áreas reservadas para serviços e infra-estrutura tem induzido algumas administrações públicas, principalmente a nível local, a empregar uma técnica de planejamento diferente, não mais focada exclusivamente no zoneamento, mas também na assim chamada "equalização urbanística" 30 . Embora seja particularmente complexo e declinável em diferentes modalidades de implementação, o conceito de equalização tem seu núcleo essencial na ideia de que, com referência a uma área territorial mais ou menos específica, pesos e vantagens são igualmente distribuídos entre os respectivos proprietários $^{31}$. A distribuição equitativa destes elimina a discriminação fisiológica decorrente do zoneamento, ao mesmo tempo em que oferece maiores garantias para a construção de espaços públicos. Isto acontece na medida em que, em virtude do mecanismo de equalização, se torna mais fácil e menos dispendiosa economicamente a aquisição de áreas para infraestruturas e serviços.

Como dito antes, muitos são os métodos para implementar a equalização, e aqui não podem ser totalmente aprofundados ${ }^{32}$. A principal técnica de equalização pressupõe a identificação 
de uma chamada "zona de equalização" que, ao contrário do que acontece com o zoneamento, une áreas com diferentes funções, como as que dependem de transformação e as que se destinam para infraestruturas ou serviços. O índice bruto global edificado é distribuído uniformemente por toda a área de equalização, para que as áreas de transformação e áreas designadas por padrões urbanísticos tenham o mesmo potencial de capacidade de construção.Tal capacidade será inferior à capacidade efetivamente atribuída, sem prejuízo do fato de a capacidade atribuída às áreas designadas como "standard" (para realização de equipamentos e infraestruturas coletivas) não poder ser concretamente utilizada nessas áreas, mas apenas nas destinadas especificamente à transformação ${ }^{33}$. Desta forma, a equalização permite que os direitos de construção se separem das áreas de origem (ou seja, dos solos "de origem", que eram potencialmente edificáveis), para "mudar o detentor e mover-se - derivado - indefinidamente, até que sejam incorporados em outro solo ("receptor") que pode ser transformado para fins de construção." (TRAINA, 2015, p. 690).

Outra forma de implementar a equalização é representada pela chamada "compensação" ${ }^{34}$, embora sua finalidade não tenha sido necessariamente pensada para coincidir com a necessidade de uma redistribuição equilibrada da capacidade construtiva. A compensação implica que o proprietário de uma área que tenha sofrido restrições possa transferi-la para a autoridade local em troca da alocação de cotas de construção a serem utilizadas em outras áreas. Desta forma, evita-se que a administração pública arque com o ônus econômico da compensação pela desapropriação, encorajando o proprietário a transferir consensualmente a propriedade em troca de um volume de construção. Também neste caso, as vantagens da compensação são suportadas simultaneamente pelo proprietário e pela comunidade. $O$ primeiro perde uma área que não pode ser usada para fins de construção com a atribuição de uma capacidade específica de construção em outra área imediatamente compensada, sem ter que esperar por uma possível compensação hipotética, incerta em seu pagamento concreto e não necessariamente adequada, e que não necessariamente garante uma recuperação econômica efetiva. Por sua vez, os cidadãos podem beneficiar-se concretamente com a celeridade das intervenções no espaço público coletivo, que se tornam mais simples e menos onerosas, pois a autoridade local não está vinculada à aplicação da disciplina de desapropriação.

Atualmente, a equalização é essencialmente regulada pela legislação regional ou, em alguns casos, diretamente pelo plano diretor municipal: portanto, a equalização entra no plano normativo italiano num quadro retro-iluminado pelo princípio da subsidiariedade (ver nota 6). Em contraste com os propósitos de equalização, a ausência de regulação nacional pode levar a uma 
maior discriminação, especialmente se o método de equalização for regulado e aplicado apenas em algumas regiões, mas não em outras. Acrescente-se a isso que é também o artigo 42, parágrafo 2으, da Constituição, que identifica uma reserva legal referente ao conteúdo e limites do direito de propriedade. Ou seja, exclui que os métodos de uso e as limitações ao direito de propriedade sejam regidos pela lei regional na ausência de uniformidade de princípio em nível nacional. Deve-se considerar, ainda, que o artigo 117, parágrafo 2으, letra I da Constituição, atribui à exclusiva competência do Estado matérias de ordem civil, na esfera da qual a matéria do direito à propriedade é pacificamente incluída pela doutrina toda.

É verdade que, conforme sublinhado na doutrina e na jurisprudência, as críticas relevantes podem ser superadas observando que, no nível nacional, o princípio fundamental relativo à equalização urbanística encontra-se já no artigo 23 da Lei de planejamento urbano de $1942^{35}$ e que a equalização urbanística seria uma expressão do poder administrativo geral de afirmação do direito de propriedade ${ }^{36}$. A competência legislativa regional não contraria a previsão constitucional que reserva a matéria de ordenamento civil à competência exclusiva estatal, uma vez que, na orientação do Tribunal Constitucional, a exclusão do legislador regional operaria apenas com referência ao direito de propriedade enquanto direito civil, na dimensão das relações intersubjetivas; mas não diz respeito "ao poder de afirmar o conteúdo do direito de propriedade para assegurar sua função social”37. Isto também seria confirmado pelo acórdão no 121 de 2010 do Tribunal Constitucional, de acordo com o qual o regulamento da transferência e cedência dos direitos de construção seria abrangido pela jurisdição do direito civil ${ }^{38}$. Por ser uma regulação relevante no contexto das relações intersubjetivas, sua atração no campo da ordem civil seria coerente com os princípios afirmados pelo juiz constitucional; mas a mesma atratividade também não poderia dizer respeito à disciplina conformativa prefigurada pelo direito constitucional ${ }^{39}$.

No que diz respeito à compensação, por outro lado, não se consideram críticas particulares de inconstitucionalidade, dado que, como confirmado pela sentença no 179 de 1999 do Tribunal Constitucional, a previsão constitucional da indenização pode ser substituída por "medidas corretivas alternativas também de uma forma específica, oferecendo outras áreas adequadas para as necessidades do sujeito que tem direito a um refresco ou através de outros sistemas de compensação que não penalizem as pessoas afetadas pelas escolhas de planejamento urbano que incidem sobre determinados bens" (CORTE CONSTITUCIONAL, 1999).

\subsection{A desapropriação simplificada. Vozes críticas em relação à garantia constitucional dos}




\section{direitos de propriedade}

Tendo em vista a progressiva consolidação dos instrumentos de equalização, atualmente o sistema jurídico italiano também se caracteriza pela previsão do instituto da "desapropriação simplificada", regulada pelo artigo 42 bis do Decreto do Presidente da República, no 380 de 2001. Em resumo, a norma dá à administração o poder de emitir a escritura de aquisição para remediar ocupações ilegais e modificações de bens imobiliários na ausência de uma justificativa válida e eficaz para a desapropriação ou para declarar a utilidade pública, impedindo assim o poder público de ser chamado a devolver uma área ocupada ilegalmente. Mais precisamente, de acordo com a disciplina examinada, a desapropriação simplificada pode ser adotada na hipótese em que o bem ocupado ilegalmente é agora usado para fins de interesse público e, como é literalmente exigido pela lei, para ser utilizado este instrumento deve ser especificamente motivado com referência ao "atuais e excepcionais razões de interesse público". Estas devem ser avaliadas comparativamente com os interesses privados opostos, destacando a ausência de "alternativas razoáveis" para a aplicação da desapropriação simplificada. Neste caso, a indenização pelos danos patrimoniais e não patrimoniais causados pela conduta ilegítima da administração deve ser paga, ordenando-se o pagamento no prazo de trinta dias.

Delineados os elementos essenciais da matéria, o artigo 42 bis apresenta aspectos críticos em relação ao artigo 42, parágrafo 3ạ, que, ao prever que "a propriedade privada pode ser, nos casos previstos em lei, desapropriada por razões de interesse geral e sujeita à indenização", sanciona a regra de que as desapropriações são admitidas apenas nos casos previstos na lei e pressupõem a existência de "razões de interesse geral".

Conforme esclarecido várias vezes, sobretudo pela doutrina, essas "razões de interesse geral" devem emergir de um procedimento específico, culminando na declaração de utilidade pública. E esta última tem que ser preliminar e autônoma em relação ao procedimento de desapropriação, no qual a administração planeja um novo bem jurídico, destinado a satisfazer um interesse público atual e concreto específico. A declaração de utilidade pública constitui, portanto, o concreto desenvolvimento da garantia constitucional, na medida em que é através desta declaração que as razões de interesse geral são identificadas antes que as obras sejam realizadas e o bem privado seja ocupado. $O$ aspecto que enfatizamos é que, ao permitir a desapropriação, mesmo na ausência da declaração de utilidade pública, a regulamentação da desapropriação simplificada admite que tal medida possa ser adotada na ausência da identificação prévia das "razões de interesse geral" e atua para justificar a criação de um novo bem para substituir aquele a ser desapropriado, eliminando a 
necessidade da declaração pública em contraste com a garantia constitucional. Somente se a escolha administrativa for consumada em um momento anterior à lesão ao direito, pode-se de fato considerar abstratamente garantido que o sacrifício da propriedade ocorre com base nas reais necessidades do poder público, assim evitando o risco de que o interesse público seja declarado posteriormente para justificar o uso de um bem ocupado ilegalmente (ZAMPETTI, 2011).

Outro aspecto crítico do regulamento é o fato de que a lei expõe o direito do privado à desapropriação sem indicar qualquer prazo dentro do qual a regularização deve ser realizada. Determina-se assim uma interminável exposição do direito de desapropriação, configurada quando, no procedimento ordinário de desapropriação, a mesma exposição é temporariamente limitada à eficácia da restrição pré-ordenada à desapropriação ou em qualquer caso da declaração de utilidade pública. Em outras palavras, o artigo 42 bis determinaria substancialmente uma "marca" na propriedade comparável às limitações impostas pelas intervenções conformativas. Mas existe uma diferença não menos importante: nesse caso, a supressão do direito resultaria em conduta ilegal da administração e o sacrifício definitivo a uma escolha administrativa a ser feita sem qualquer limitação de tempo. O próprio fato de que a supressão da propriedade decorre de um uso incorreto do poder administrativo dificulta a assimilação do sacrifício do direito de propriedade privada a um dos propósitos da utilidade social exigidos pelo artigo 42, alínea 2 da Constituição, para justificar a intervenção conformativa. Assim revela, também a esse respeito, um possível viés de inconstitucionalidade do instituto da desapropriação simplificada.

No entanto, com a sentença de no 71 de 2015, o Tribunal Constitucional passou a reconhecer a legitimidade constitucional do instituto em exame, valorizando seu caráter excepcional. O pressuposto de partida é que o ato de desapropriação seria adotado como último recurso exclusivamente para a satisfação de "razões atuais e excepcionais de interesse público", nos casos em que, na sequência de uma comparação efetiva com os interesses privados opostos, tenham sido excluídas outras opções e não seja razoavelmente possível reembolsar total, parcial ou integralmenteao particular ilegalmente atingidoem seu direito de propriedade no valor equivalente à situação pre-existente ao ato. As conclusões da Corte acabam por não serem convincentes, especialmente por não conseguirem ultrapassar o fato pelo qual as razões de interesse geral subjacentes à adoção da disposição aquisitiva não são de todo predeterminadas, como seria exigido pela disposição constitucional. De fato, elas são apenas deduzidas posteriormente, com base numa situação definitivamente comprometida pela conclusão das obras. 
Embora com as suas ambiguidades e limitações, os dois instrumentos aqui mencionados constitueam uma superação irreversível do tradicional planejamento por zoneamento, no qual a nunca reformada legislação italiana do ordenamento do território ainda afunda suas raízes, a partir dos parênteses fascistas dos anos 1920-40. O zoneamento, de fato, vinculava a construção daquela que aqui chamamos de "cidade pública" baseando-se essencialmente no instrumento de desapropriação, o qual demonstrou-se 1) complexo e irrealista na sua aplicação concreta, 2) muitas vezes incerto nos resultados finais, e 3) dispendioso economicamente, até o ponto que nem mesmo o recente instrumento da desapropriação simplificada (para os perfis críticos expostos acima, de nível constitucional) parece em condições de revitalizá-lo adequadamente. Portanto, a ambição de renovar e inovar (gradual e continuamente) as maneiras de efetivar a função social da propriedade deverá prioritariamente partir do modelo atual de equalização: e isto parece já estar parcialmente acontecendo, conforme veremos no próximo tópico.

\section{Conclusões: olhando para um futuro de hibridização entre instrumentos}

No presente artigo, a partir de uma perspectiva principalmente histórico-sociológica, analisamos a complexa e problemática trajetória da legislação italiana na efetivação de uma das componentes específicas importantes do Direito à Cidade, ou seja, a "função social da propriedade". Nomeadamente, destacamos as tentativas, mais ou menos bem-sucedidas, de combinar a dimensão privada da propriedade com sua projeção pública (claramente prefigurada no artigo 42 da Constituição), para depois aprofundar a análise de dos dois instrumentos jurídicos centrais usados hoje - no âmbito do planejamento urbano - para efetivar essa função social dos solos. A atenção dada no texto à proposta de reforma do então ministro Sullo (que nunca entrou em vigor devido aos conflitos nas forças políticas da época e também no próprio governo) assim como às ambiguidades e criticidades de algumas medidas regulamentares sucessivamente aprovadas, serviu para demonstrar claramente como: 1) a transformação da administração pública sempre foi um âmbito inerte (e marginalizado) da evolução do quadro legislativo italiano; 2) que a possibilidade de avançar (ou menos) com modificações normativas desafiantes foi condicionada pela existência de blocos e alianças sociais críticas ou favoráveis às diferentes medidas, dentro de um quadro político pouco corajoso, marcado por posturas "eleitoreiras" mais interessadas em garantir resultados eleitorais favoráveis do que em marcar etapas importantes no cumprimento do interesse comum; 3 ) que as forças progressistas que hoje (parcialmente) reivindicam a efetivação do Direito à Cidade, por muito tempo tardaram a compreender os riscos trazidos pelos blocos de 
especuladores urbanos que - nos anos sessenta - substituíram o tradicional bloco social ligado aos latifúndios agrícolas; 4) que avanços e recuos no comprimento da função social da propriedade urbana foram parcialmente favorecidas pelas interpretações dadas pelo poder judiciário (nas suas diferentes instâncias) como pelas reformas federativas que incrementalmente contribuíram para regulamentações (ou leituras) mais inovadoras dos instrumentos existentes por parte de regiões e municípios; 5) que, finalmente, os instrumentos hoje mais usados para cumprir, no planejamento urbano, os deveres de função social da propriedade, conseguiram ultrapassar muitos dos limites do tradicional zoneamento funcionalista, mas permanecem ainda carregados de ambiguidades tanto na sua estruturação quanto no seu uso.

A este último ponto é dedicada a análise mais aprofundada (proposta no tópico 3 do artigo de um ponto de vista exclusivamente jurídico) das duas ferramentas do variado e heterogêneo panorama de instrumentos para a efetivação da função social da propriedade urbana que se tornam centrais na atual disciplina de desapropriação: 1) a equalização e 2) o instituto da "desapropriação simplificada". Este ultimo aparece indispensável num país onde o estado faz parte de comportamentos que representam escolhas processualmente ilegítimas - até no interesse público - que precisam de ser redirecionadas e remediadas a posteriori.

Conforme realçado, as duas ferramentas parecem exemplificar claramente, no estado atual do sistema, a tensão entre a dimensão pública e privada da propriedade, esculpida na Constituição italiana.

Sem dúvida, o estudo (que recolhe e reelabora uma ampla literatura jurídica, favorecendo um diálogo com aquela que hoje defende a efetivação do Direito à Cidade) revela como um tema essencial na Constituição - e sempre presente no debate e no clima político-sócio-cultural do país não se materializou adequadamente na legislação positivada.

Se uma instituição como a equalização do planejamento urbano, embora com suas questões críticas, tende a alcançar um bom equilíbrio na tensão entre dimensão pública e privada do direito à propriedade, a desapropriação simplificada (na forma esboçada mas ainda não refinada pelo legislador) demanda - ao contrário - um sacrifício percebido como excessivo da dimensão privada dos direitos de propriedade, e faz isso por motivos de interesse público substancialmente identificados apenas "ex post", ou seja, após a realização de obras públicas. 
Neste sentido, como costuma acontecer em geral para a experiência jurídica, tem-se que esperar que as necessidades da sociedade possam gradualmente impor as soluções mais eficazes à lei para regular a tensão público-privada no exercício do direito de propriedade.

No final, vale a pena realçar o fato de que, além da dimensão puramente jurídica, alguns limites adicionais da equalização são particularmente destacados pelas correntes do planejamento urbano crítico. O primeiro é a incerteza dos prazos de implementação das previsões, pois eles dependem da capacidade de cooperação dos proprietários entre si e com o estado. O segundo é o fato de a equalização ter como pressuposto "uma lógica de aumento gradual da urbanização que colide com a necessidade - hoje cada vez mais sentida - de reduzir o consumo do solo" (TRAINA, 2015, p. 697).

Nessa perspectiva, a equalização parece chegar "atrasada" para regular os projetos de expansão, quando já os planos de desenvolvimento urbano revelam-se necessários, acima de tudo, para atuar na recuperação das áreas existentes já edificadas (os chamados brownfields), na melhoria de áreas construídas e livres, na recomposição das áreas marginais e na lógica dos "volumes zero". Portanto, não é coincidência que o diálogo progressivo e crescente entre urbanistas e juristas encontre convergência na necessidade de integrar a equalização com referências a "concursos" que permitam selecionar as melhores propostas de uso do solo urbano possível em cada situação concreta. Colocar essas propostas em concorrência (de forma transparente e imparcial) entre os proprietários de todas as áreas potencialmente adequadas para construção dentro de um determinado território pode ser uma modalidade interessante para o futuro. Trataria-se de integrar uma concepção liberal da cidade com preocupações sociais que a veem como um importante instrumento para criar e "distribuir" o bem-estar. Sem produzir nenhuma visão revolucionária, esta hibridização temperada poderia favorecer uma superação da equalização, cujo uso é "inexoravelmente limitado às áreas de desenvolvimento" (CAMAGNI, 2008). A sinergia entre diferentes instrumentos (equalização e concursos entre projetos de urbanização) poderia ser vista também como a maneira mais viável e adequada de fortalecer - em essência e não de um ponto de vista puramente formal - o princípio de planejamento e uma promoção "realista" do interesse coletivo máximo, também em termos da qualidade de construção arquitetônica dos assentamentos e dos equipamentos públicos.

Para finalizar, merece destacar que difusão desses procedimentos híbridos é ainda limitada, sobretudo devido à determinação que se exige das administrações para enfrentar uma nova fase de experimentação criativa com caminhos ainda pouco traçados (CAMAGNI, 2008), mas ela é vista por muitos autores como uma inovação adequada aos planos urbanísticos "de última geração 
inspirados no quam maxime à limitação de uso do solo e à recuperação das áreas já ocupadas" (TRAINA, 2015, p. 700). A adoção de uma prática de valorização da função social dos solos, baseada em um modelo de "concurso" dos "planos detalhados" (PP) está ainda em teste na Itália, mas parece cada vez mais representar uma hipótese desejável em um quadro de demandas sociais centradas na maximização da eficiência e, acima de tudo, da justiça social. Ainda, tal prática consolidaria uma opção política claramente inspirada nos princípios constitucionais de igualdade e imparcialidade, e portanto perceptível como mais "legítima" do que os modelos e as técnicas que o precederam, e que citamos no tópico 3.

Em qualquer caso, enquanto a transformação dos modelos de planejamento acontece lentamente, a consolidação da função social da propriedade (como componente importante para a efetivação de uma das dimensões centrais do Direito à Cidade) requer a articulação dos instrumentos existentes, não apenas entre si, mas também com outras políticas inovadoras. Por exemplo, o instituto da equalização (hoje amplamente aceita e consolidada) poderia ser articulado com a criação dos chamados Bancos de Terras (por vezes conhecidos como Bolsas de Terra) ${ }^{40}$. Estes servirão não apenas para identificar uma reserva de áreas públicas que possam ser usadas para facilitar o intercâmbio de terrenos e índices (POMPEI, 1998), mas também para permitir o uso temporário de terrenos. Tais usos (como a criação de hortas urbanas para agricultura social) seriam úteis para maximizar a função social da propriedade com o propósito de criar políticas públicas que visem aumentar a qualidade de vida dos habitantes, a estética das paisagens urbanas e o meio ambiente. Mas - acima de tudo - serviriam para tornar mais exigíveis os direitos sociais e econômicos dos cidadãos e (em particular) dos grupos sociais mais vulneráveis.

\section{Bibliografia}

ALLEGRETTI, Umberto. Diritti e Stato nella mondializzazione. Troina: Città Aperta, 2002.

ALLEGRETTI, Umberto. L'Amministrazione. Dall'attuazione costituzionale alla democrazia partecipativa. Milano: Giuffrè, 2009.

ALLEGRETTI, Umberto. Storia costituzionale italiana. Bologna: il Mulino, 2014.

ASTENGO, Giovanni. Urbanistica in Parlamento. Urbanistica, n. 36/37, pp. 2-10, 1962.

BARTOLINI Antonio; MALTONI, Andrea (org.). Governo e mercato dei diritti edificatori:

esperienze regionali a confronto. Napoli: EditorialeScientifica, 2009. 
BLEČIČ, Ivan; CECCHINI, Arnaldo. A cinquant'annidalla proposta di reforma urbanística di Fiorentino Sullo, 2013. In Eddyburg.it: http://www.eddyburg.it/2013/08/a-cinquantanni-dallaproposta-di.html

BORJA, Jordi; MUXİ, Zaida. El espaciopublico: ciudad y ciudadania. Barcelona: Electa, 2003.

BOSCOLO, Emanuele. Dalla zonizzazione ala perequazione urbanística. Riv. giur. edil., Milano, n.

4., 2000,21 e ss.

CACCIAVILLANI, Chiara. La perequazione urbanística nell'esperienza italiana. D'ORSOGNA, Domenico (org.) Perequazione urbanistica. Materiali per la comparazione giuridica. Torino: Giappichelli Editore, 2015.

CAMAGNI, Roberto. Il finanziamento dela città pubblica - In BAIONI, Mauro (org.), La costruzione dela città pubblica. Firenze: Alinea, 39-57, 2008.

CAMAGNI, Roberto. II finanziamento dela città pubblica: lacattura dei plus valori fondiari e il modelo perequativo. In CURTI, Fausto (org.), Urbanistica e fiscalità locale, Ravenna: Maggioli, pp. 321-342, 1999.

CAMAGNI, Roberto. L'uso improprio dela perequazione urbanistica: il caso del PGT di Milano.

EyesReg, Vol.1, N. 1, Maggio 2011.

CARBONE, Andrea; D'ANGELO, Flaminia; PULCINI, Emilia. L'evoluzione del potere di pianificazione nella giurisprudenza amministrativa. In URBANI, Paolo (org.) Politiche urbanistiche e gestione del territorio. Torino: Giappichelli Editore, 2015.

CARLOS, Ana Fani. A condição espacial. São Paulo: Contexto, 2011.

CEDERNA, Antonio. Mussolini urbanista. Los ventramento di Roma negli anni del consenso. Venezia: Corte delFontego, 2006.

CERBO, Paolo. Profili di costituzionalità dela c.d. acquisizione sanante. Urb. e app., n. 2, 208 e ss; 2009.

CERULLI IRELLI, Vincenzo, "Statuto costituzionale dela proprietà privata e poteri pubblici di pianificazione, in URBANI, Paolo. Politiche urbanistiche e gestione del territorio. Torino: Giappichelli, 2015, pp. 11 ss.

CORTE COSTITUZIONALE. Acórdão n. 179, 1999. Em: www.cortecostituzionale.it CORTE COSTITUZIONALE. Acórdão n. 71, 2015. Em: www.cortecostituzionale.it D'ORSOGNA, Domenico, Perequazione urbanistica. Materiali per la comparazione giuridica, Torino: Giappichelli, 2015.

DEFELICE, Franco.L' Italia repubblicana. Nazione e sviluppo. Nazione e crisi. Torino, Einaudi, 2003. 
DE LUCIA, Vezio. Nella Città Dolente. Mezzo secolo di scempi, condoni e Signori del cemento, dalla sconfittadi Fiorentino Sullo a Silvio Berlusconi. Roma: Castelvecchi, 2013.

FERRARESI, Franco; TOSI, Antonio. Crisidellacitta' e politica urbana. In GRAZIANO Luigi;

TARROW, Sidney (org.), La crisi italiana. Torino: Einaudi, 1979.

FUBINI, Antonio.Urbanistica in Italia. Milano: CLUP, 1978.

GARCIA, Eva; ALLEGRETTI, Giovanni. El derecho a laciudaden Europa. In SAULE JÚNIOR, Nelson; ZÁRATE, Lorena; EMANUELLI, Maria Silvia. (org.), Avanzando em la Implementación del Derecho a la Ciudad en América Latina y a nivel Internacional, S. Paolo: Polis/HIC/Fondazione Ford, pp. 69-144.

GEORGESCU-ROEGEN, Nicholas. The Entropy Law and the Economic Process. Cambridge: Harvard University Press, 1971.

GIACCHETTI, Salvatore. Problemi esistenziali dela giurisdizione amministrativa.www.giustizia-a mministrativa.it, a. 3, n. 3, 135-145, 2008.

GINSBORG, Paul. Storia d'Italia dal dopo guerra a oggi. Società e politica 1943-1988. Torino:

Einaudi, 1989.

GIUSTINIANI, Corrado. La casa promessa. Torino: Einaudi, 1981.

GOGGIAMANI, Francesca. Limitiscritti e non scrittiall'art. 43 del Testo Unico n. 327 del 2001.

Foro amm. - Cons. St., Milano, pp. 2109 ss.;2005.

GRAZIOSI, Benedetto. Figure poliformi di perequazione urbanistica e principio di legalità. Rivista Giuridica dell'edilizia, II, 147 e ss, 2007.

HARVEY, David. Rebel cities. From the right to the city to the urban revolution. London/New York: Verso, 2012a.

HARVEY, David. Il capitalismo contro il diritto ala città. Neoliberalismo, urbanizzazione, resistenze. Verona: Ombre Corte, 2012b.

LATOUCHE, Serge. Pequeno tratado do crescimento sereno. São Paulo: Martins Fontes, 2009.

LÉFÈBVRE, Henri. Le Droit à laVille. Paris, ÉditionsAnthropos, 1968.

LÉFÈBVRE, Henri. La Production de l'espace. 3a ed. Paris: Ed. Anthropos, 1974.

LEONE, Giovanni; MAROTTA, Alessandro. L'espropriazione per pubblica utilità. Rassegna di Giurisprudenza, CEDAM, 1993.

LICCIARDELLO, Sebastiano. Autonomie e uso delterritorio, in MARINO Ignazio Maria;

LICCIARDELLO, Salvatore; BARONE, Antonio(org.). L'uso del territorio. Milano: Giuffrè, 2004.

LICCIARDELLO, Sebastiano (2007), Espropriazioni e giurisdizione. Torino: Giappichelli, 2007.

LUCIANI, Massimo “Corte costituzionale e proprietàprivata. Giur. cost., I, pp. 1384 e ss., 1977. 
MACARIO, Francesco. Commentoall'art. 42 dellaCostituzione.In BIFULCO, Raffaele; CELOTTO, Alfonso; OLIVETTI, Marco. Commentario ala Costituzione. Torino: UTET, 2006 MAGRI, Lucio, Una Legge per laCittà. Rinascita, 24 agosto 1963.

MANNORI, Luca; SORDI, Bernardo. Storia del Diritto Amministrativo. Bari: Laterza, 2004. MARCHI, Marzia. Il volto sociale dell' “edilizia popolare”. Roma: Sapere, 1975. MONTARULI, Vito (2008), La funzione sociale dela proprietà nella Costituzione italiana e nella Convenzione europea per la salvaguardia dei diritti dell'Uomo. Diritto costituzionale, 10/07/2008. In: http://www.diritto.it/docs/26291-la-funzione-sociale-della-propriet?page=2MORBIDELLI, Giuseppe. Della perequazione urbanistica. Giustamm.it, 6/2009. NATOLI, Aldo. ParaboladiSullo. In Rinascita, 25 aprile 1964, www.eddyburg.it PABA, Giancarlo. Corpi urbani. Differenze, interazioni, politiche. Milano: Franco Angeli, 2010. PALADIN, Livio. Per una storia costituzionale dell'Italia repubblicana. Bologna: il Mulino, 2004. PARLATO, Valentino. II blocco edilizio. In INDOVINA, Francesco (coord.). Lo spreco edilizio. Venezia: Marsilia, 1979.

POLICE, Aristide. Governo e mercato dei diritti edificatori. In BARTOLINI, Antonio; MALTONI, Andrea (coord.). Governo e mercato dei diritti edificatori: esperienze regionali a confronto, Napoli: Editoriale Scientifica, 2009.

POMPEI, Stefano. II Piano regolatore perequativo. Aspetti strutturali, strategici e operativi, Milano: Hoepli. 1989

PUGLIATTI, Salvatore. La proprietà nel nuovo diritto. Milano: Giuffré, 1954.

ROCHAT, Giorgio et al. La casa in Italia: 1945-1980: alle origini del potere democristiano. Bologna: Zanichelli, 1980.

RODOTÀ, Stefano. Il terribile diritto - Studi sulla proprietà privata, Bologna, II Mulino, 1981 (ver também segunda edição atualizada. Bologna, il Mulino, 1990).

RUGGE, Fabio. Il disegno amministrativo: evoluzioni e persistenze. In AAVV, Storia dell'Italia repubblicana. Torino, Einaudi, 1995.

SALZANO, Edoardo. La città bene comune, Bologna: Baiesi, 2009.

SALZANO, Edoardo. Fiorentino Sullo e la rendita immobiliare. Che cosa è cambiato. In www.appelloalpopolo.it, paper na Accademia Galileiana de Padua, 20 outubro de 2010. SANDULLI, Aldo Maria. I limiti della proprietà privata nella giurisprudenza costituzionale.Giur. Cost., 962-970., 1971. SCOCA, Franco Gaetano; TARULLO, Stefano. La metamorfosi dell'accessione invertita: I'atto di acquisizione di immobili utilizzati sine titulo. Riv. amm. rep. it.,Vol. 152, 7, 531-553, 2001. 
SETTIS, Salvatore. Italia S.p.A.. Torino: Einaudi, 2002.

SOJA, Edward. Seeking Spatial Justice. Minnesota: University of Minnesota Press, 2010.

SORACE, Domenico.Espropriazione della proprietà e misura dell'indennizzo. Milano: Giuffrè, 1974.

SORACE, Domenico. Espropriazione per pubblica utilità, in Dig. disc. pubbl., VI, Torino, Utet, 1991.

SOUZA, Paulo Fernando Mohn e (2010), A subsidiariedade como princípio de organização do Estado e sua aplicação no federalismo. Brasília: Senado Federal, Subsecretaria de Edições Técnicas.

In:

http://www2.senado.leg.br/bdsf/bitstream/handle/id/221279/890390.pdf?sequence=1

STELLA RICHTER, Paolo, Il potere di pianificazione nella legislazione urbanistica. Rivista Giuridica dell'Edilizia, II, pp. 103 e ss., 1969.

STELLA RICHTER, Paolo. "Relazione generale" no Congresso "La semplificazione nella disciplina del territorio" (Trento, 8-9 outubro de 2010). Rivista giuridica di urbanistica, n. 17, Jan/jun, pp. 11-30, 2012.

STELLA RICHTER, Paolo. Diritto Urbanistico. Milano, Giuffré, 2014.

SULLO, Fiorentino. Lo scandalo urbanistico. Firenze: Vallecchi, 1964.

TAMBURRANO, Giuseppe. Storia e Cronaca del Centro Sinistra. Milano: Feltrinelli, 1976.

TELÒ, Mario. L'Italia nel processo di costruzione europea, in AAVV Storia dell'Italia repubblicana. Torino, Einaudi, 1966.

TRAINA, Duccio Maria. Entrada "Perequazione Urbanistica". Enciclopedia del Diritto, Annali VIII. Milano: Giuffrè, pp. 687-702, 2015.

URBANI, Paolo; CIVITARESE MATTEUCCI Stefano. Diritto urbanistico. Torino: Giappichelli, 2013. URBANI, Paolo (org.). Politiche urbanistiche e gestione del territorio. Torino: Gaippichelli, 2015. URBANI, Paolo. Gli istituti della perequazione urbanistica e della compensazione urbanistica tra interpretazioni giurisprudenziali e vuoti normativi. In SCOCA, Franco Gaetano; STELLA RICHTER, Paolo; URBANI, Paolo (org.). Trattato di diritto del territorio. Torino: Giappichelli, 705 ss, 2018. URBANI, Paolo. Urbanistica solidale. Torino: Vollati Boringhieri, 2011.

VERBARI, Gianbattista. La dichiarazione di pubblico interesse. Milano: Giuffré, 1973.

VOLPE, Francesco. Acquisizione amministrativa e acquisizione giudiziaria nel sistema delle espropriazioni per pubblica utilità. In Giustamm.it, 47, 1-51, 2008.

ZAMPETTI, Enrico. Acquisizione sanante e principi costituzionali. Diritto Amministrativo, n. 3, p. 569 e ss., 2011. 
1 A perspectiva disciplinar diferente das duas seções reflete a formação heterogênea dos autores (urbanístico/sociológica no caso de Giovanni Allegretti, prevalente no tópico 2, e jurídica no caso de Enrico Zampetti, principalmente no tópico 3). Os autores agradecem Umberto Allegretti pelo apoio logístico durante a pesquisa bibliográfica e pelas animadas discussões para definir sua estrutura, e Sheila Holz pela tradução (e as numerosas revisões) do artigo.

${ }^{2}$ Fala-se aqui de Lei de Base, em referência ao texto legal com as diretrizes gerais da matéria (neste caso o Urbanismo), sobre o qual - por exemplo - as Regiões têm competências que devem ser regular com leis específicas.

${ }^{3}$ Trata-se da Lei nacional n. 1150/1942, de 17 de agosto de 1942, unanimemente considerada pela crítica uma lei de base avançada para a época (CEDERNA, 2006).

${ }^{4}$ Equivalentes aos Estados no modelo Federativo Brasileiro.

${ }^{5}$ Nos referimos aqui às assimetrias existentes entre os regulamentos criados pelas diferentes regiões do país, por seus Parlamentos Regionais, como também aos atrasos, de muitas delas, na elaboração de suas leis específicas. A Toscana é considerada o "carro-chefe" das reformas mais eficazes em matéria de urbanismo e planejamento do território, e já passou por três reformas importantes (em 1995, 2005 e 2014), tendo o hábito de avaliar e reformular as suas Leis a cada década.

${ }^{6}$ Trata-se de um princípio-base da organização da União Europeia, que regula a maneira com que são concebidas as legislações dos estados membros. A finalidade geral do princípio da subsidiariedade (que origina historicamente na patrística católica dos seculo V e VI dC) é "garantir um determinado grau de autonomia a uma autoridade subordinada a uma instância hierarquicamente superior, ou a uma autoridade local em relação ao poder central", fazendo com que as decisões começem a ser tomadas primariamente nos níveis institucionais mais próximnos aos cidadãos, sempre que tomá-las a um nível superior não as torne mais eficazes e viáveis. Ver: https:/www.europarl.europa.eu/ factsheets/pt/sheet/7/o-principio-da- s ubsidiariedade. Para o público brasileiro, aconselha-se a leitura de SOUZA (2019).

${ }^{7}$ O termo "decrescimento" é um conceito econômico/político cunhado na década de 1970 por André Gorz, e parcialmente baseado nas teses do economista romeno e criador da bioeconomia, Nicholas GEORGESCU-ROEGEN (1971), convencido que a economia neoclássica - centrada no objetivo de aumento constante do Produto Interno Bruto (PIB) - não é sustentável pelo ecossistema global. Segundo os defensores do decrescimento (LATOUCHE, 2009) os recursos naturais são limitados e, portanto, não pode existir crescimento infinito; assim, a melhoria das condições de vida deve ser perseguida sem aumento do consumo, mudando-se o paradigma dominante com estilos de vitas mais sóbrios e menos extrativistas.

${ }^{8}$ Até 1989, na Itália, o “pretor” era um juiz singular (a jurisdição era exercida por um único magistrado e não por um colegiado) a quem foi confiada a jurisdição em questões civis e criminais, bem como importantes tarefas administrativas e de jurisdição voluntária. Entre eles, por exemplo, julgamentos de oposição a penalidades administrativas ou trabalhistas e previdenciárias, ou as funções de juíz tutelar. A "pretura" (primeira instância) estava localizada nas capitais provinciais. O estabelecimento do "Giudicedipace” (Justiça de Paz) em 1991 absorveu, além das funções dos juízes de conciliação, também algumas das funções que no passado pertenciam aos "pretores". O decreto legislativo no 51, de 19 de fevereiro de 1998, suprimiu definitivamente a figura do pretor, substituindo-o pelo "juiz único de primeiro grau", para todos os julgamentos civis (desde junho de 1999) e para julgamentos criminais (desde janeiro de 2000); este juiz é monocrático, exceto em casos raros, a lei estabelece estritamente a composição colegial.

${ }^{9}$ Embora o termo não seja muito adequado à norma culta da escrita brasileira, ele reflete exatamente o termo provocativo de "burocraziedel quotidiano" usado pelo autor citado.

${ }^{10}$ Esta transformação deveria permitir maior margens de autonomia da política para os altos cargos dirigentes, mas acabou os responsabilizando de forma que - por medo das consequênciais legais - facilitou a inércia e a paralisia de muitas possíveis reformas. Também, a manutençaõ de patamares complexos e incompreensíveis dos procedimentos administrativos revelou-se uma maneira convergente (da política e dos altos cargos tecnocráticos) de manter inalterado seu grau de poder e reduzir a "social accountability" e o controle da população sobre os seus atos.

${ }^{11}$ Ver, por exemplo, GINSBORG, 1989; PALADIN, 2004 e ALLEGRETTI, 2014

${ }^{12} \mathrm{O}$ filme "Hands over the City" (Le mani sulla città) relata um implacável corretor de imóveis napolitano (que também foi eleito vereador), que consegue usar o poder político para obter lucro pessoal em um 
negócio imobiliário suburbano de largo porte No entanto, após o colapso de um prédio residencial, outro vereador inicia uma investigação sobre a possível conexão do corretor imobiliário ao acidente, descobrindo esquemas de corrupção ligados à venda de áreas edificáveis e à mudanças de uso do solo nos planos de desenvolvimento urbano.

${ }^{13}$ Ver TESTA (1962), citado em PALADIN, 2004, p. 183.

${ }^{14}$ Veja a entrevista de março de 1979, citada em GIUSTINIANI, 1981 (p. 66).

15 Conforme o título de "Il Tempo" de $1^{\circ}$ de abril de 1963: "Oito milhões de chefes de famílias decidiram defender suas casas".

16 Conforme declaração de Moro no jornal "il Popolo", em 13 de abril de 1963, quando ainda não era primeiro ministro.

17 “O escândalo urbanístico" não dispõe de uma versão em língua portuguesa.

${ }^{18}$ Citação em TAMBURRANO, 1976, pp. 283-284.

19 Trata-se da Lei no 765 de 6 de agosto de 1967 (publicada no Diário Oficial de 31 de agosto de 1967, nº 218), cujo nome está vinculado ao Ministro de Obras Públicas da época, Giacomo Mancini. A lei foi regulada pelo Decretos Ministeriais n ${ }^{\circ} 1404$, de 1 de abril de 1968, $n^{\circ} 1444$ de 2 de abril de 1968, sobre padrões de planejamento urbano e as distâncias entre construção e tráfego, ligadas ao zoneamento.

${ }^{20}$ As obras de urbanização primária são aquelas definidas no artigo $4^{\circ}$ da lei 847, de 1964 , e dizem respeito, por exemplo, à abertura de ruas, estacionamento, rede de fornecimento de água e coleta de esgoto, iluminação elétrica pública e privada, áreas verdes, dentre outros.

${ }^{21}$ As obras de "urbanização secundária" são definidas no artigo 44 da lei 865, de 1971, e suas alterações, e dizem respeito, por exemplo, à construção de creches, escolas básicas, edifícios de comércio, igrejas e outros edifícios religiosos, instalações desportivas, centros sociais e instalações culturais e de saúde, bem como implementação de áreas verdes.

${ }^{22}$ Trata-se da lei $n^{\circ} 865$, de 22 de outubro de 1971, relativa a programas e coordenamento para a construção de habitação pública.

${ }^{23}$ A CEDH é uma convenção internacional elaborada e adotada no âmbito do Conselho da Europa, com um mecanismo jurisdicional permanente que permite a cada indivíduo solicitar a proteção dos direitos garantidos na mesma, através do recurso ao Tribunal Europeu de Direitos Humanos, localizado em Estrasburgo (França). Assinado em Roma, em 4 de novembro de 1950, pelos 12 Estados que compunham o Conselho da Europa, entrou em vigor em 3 de setembro de 1953, mas na Itália somente em 10 de outubro de 1955, vendo sua força ser reforçada somente após as chamadas "sentenças gêmeas", de nº 348 e 349 de 2007) do Tribunal Constitucional. A CEDH foi então integrada e modificada por 14 protocolos adicionais, que entraram em vigor entre 1970 e 2004 (o último autorizou que organizações internacionais, como a União Europeia, se tornassem parte da Convenção, o que aconteceu posteriomente com a aprovação do artigo 6, alínea 2, do Tratado de Lisboa, que entrou em vigor em $1^{\circ}$ de dezembro de 2009). Atualmente, dois outros protocolos aguardam entrada em vigor.

${ }^{24}$ No artigo 42 afirma-se que "A propriedade privada é reconhecida e garantida por lei, que determina como é adquirida, desfrutada e seus limites, a fim de assegurar sua função social e torná-la acessível a todos" e que "pode ser, nos casos previstos em lei, e sujeitos a indenização, expropriados por razões de interesse geral". No artigo 43 está previsto que "para fins de utilidade geral a lei pode originalmente reservar ou transferir, por desapropriação e sujeito a compensação, ao Estado, a órgãos públicos ou a comunidades de trabalhadores ou usuários, a certas empresas ou categorias de empresas, que se referem a serviços públicos essenciais ou às fontes de energia ou às situações de monopólio e são de interesse geral preeminente". O artigo 44 especifica que "A fim de alcançar a exploração racional da terra e estabelecer relações sociais justas, a lei impõe obrigações e restrições à propriedade privada da terra, estabelece limites para sua extensão de acordo com as regiões e áreas agrárias, promove e exige a recuperação de terras, a transformação de grandes propriedades e a reconstituição de unidades produtivas; ajuda a pequena e média propriedade". O artigo 42 da Constituição, com sua ambiguidade (sem dúvida evoluindo em comparação ao Estatuto Albertino de 1848), é visto por alguns exegetas como uma boa metáfora para as duas almas da Itália que produziram "mediação" constitucional (ver ALLEGRETTI, 2009).

25 Por "setores urbanísticos" entende-se a unidade mínima para a realização das intervenções de transformação urbana consistindo - por exemplo - em renovações urbanas, novos edifícios, substituições, deslocações e realocações etc., de acordo com o Plano Diretor vigente, para a aplicação da equalização, compensação e recompensa (entendida como formas de atribuição de um direito adicional de construção, reconhecido como recompensa pelo alcance dos objetivos específicos definidos em um Plano ou Regulamento de Planejamento Urbano). Normalmente, o Setor é implementado através de um plano de implementação definido entre os interessados (ou por uma maioria deles) para induzir os proprietários a 
cooperar entre si e a regular as suas relações recíprocas sob o aviso de desapropriação a favor do Município ou de uma maioria qualificada (três quartos do valor do setor) para realizar o efeito configurado pelo plano. Isto tende a produzir "naturalmente" efeitos de equalização (TRAINA, 2015, p. 690), uma vez que garante uma distribuição justa dos ônus e benefícios entre os proprietários interessados.

${ }^{26}$ Em italiano o termo é "acquisizionesanante", instituto que não encontra par no direito brasileiro. Tem como características a possibilidade que uma entidade pública - que tem modificado para fins de interesse publico um bem imóvel do qual não detem a propriedade (em ausência de uma medida eficaz de experopriação ou requisição para utilidade pública) - adquira o bem ou se acorde posteriormente com o legitimno proprietário para alguma forma de cessão.

${ }^{27}$ Entre as reflexões mais importantes sobre a função social, devemos mencionar os estudos de S. RODOTÀ (1981). Oferecendo uma articulada reconstrução do debate que se realizou na Assembléia Constituinte, destaca-se que a referência contida no art. 42 da Constituição para a função social é fruto do desejo de abandonar a concepção liberal de propriedade para transferir o direito de propriedade para fora do sistema de direitos de personalidade invioláveis. Sem qualquer pretensão de limitar a pesquisa, sobre o assunto ver também PUGLIATTI (1954); SORACE (1974); SANDULLI (1971, 962); LUCIANI (1977, I, 1384);

LEONE e MAROTTA (1993); e MACARIO (2006, 864), o qual indica outras referências bibliográficas adicionais.

${ }^{28}$ Sobre as relações entre a reserva legal contida no art. 42 da Constituição e poder administrativo, o Tribunal Constitucional, com sentença $\mathrm{n}^{\circ} .38$ do 14 de Maio de 1966, enfatizou que "o art. 42, sobre o gozo e uso dos bens, pede ao legislador comum, assim como o art. 41, a padronização relativa a posições subjetivas consideradas constitucionalmente relevantes, com a possibilidade de que a disciplina concreta das mesmas seja atribuída à administração pública ", especificando que" essa atribuição de poder deve ser considerada legítima, se, no direito comum, existirem elementos e critérios adequados para delimitar claramente o poder discricionário da administração".

${ }^{29}$ É importante destacar que, tradicionalmente, a jurisprudência do Tribunal Constitucional exclui que as intervenções que afetam o conteúdo essencial da propriedade possam ser consideradas "conformativos", impedindo efetivamente o exercício do direito. Nesses casos, o Tribunal excluiu a possibilidade de intervenção em termos meramente conformativos, remontando a uma intervenção de desapropriação com todas as implicações relacionadas, incluindo o direito a indenização constitucionalmente reconhecida pelo artigo 42, co.3 (TRIBUNAL CONSTITUCIONAL, 20 de janeiro de 1966, n. 6 e 29 de maio de 1968, n. 55, em www.cortecostituzionale.it). Para uma análise mais aprofundada da jurisprudência do TC, ver SANDULLI (1971, 966); LUCIANI (1977, p. 1345). Mais recentemente, ver CERULLI IRELLI (2015, 11); CARBONE, D'ANGELO,PULCINI (2015, p. 325).

${ }^{30}$ Como será aprofundado mais a frente, a chamada equalização é essencialmente regida por legislação regional, uma vez que não existe atualmente legislação nacional de referência. Como exemplo de legislação regional sobre equalização, pode-se fazer referência à lei regional no 12, da Região da Lombardia, de 11 de março de 2005, ou à lei regional no 11, da Região Vêneto, de 23 de abril de 2004. Em alguns casos, não existe legislação regional e a regulação da equalização é feita diretamente a nível administrativo, nos planos diretos municipais, com alguns aspectos críticos, especialmente em relação à reserva legal prevista pela lei constitucional (nestes isto, ver acima).

${ }^{31}$ Sobre a equalizaçãourbanística, ver emparticular: BOSCOLO $(2000,21)$; BARTOLINI e MALTONI (ed., 2009); POLICE (2009, 33); MORBIDELLI (2009); STELLA RICHTER (2014); URBANI (2011); URBANI (editado por) 2013; URBANI (ed. 2015); URBANI, CIVITARESE e MATTEUCCI (2013); D'ORSOGNA (ed., 2015); TRAINA $(2015,687)$.

32 Referimo-nos, por exemplo, à chamada equalização parcial ou de setor, prevista em seu núcleo original no artigo 23 da lei no 1150, de 17 de agosto de 1942 (conhecida como Lei de planejamento urbano) ou para a chamada equalização generalizada, que pode abranger todo o território municipal (para este tópico, ver STELLA RICHTER $(2014,58)$; URBANI $(2011,139)$.

${ }^{33}$ TAR Lombardia, Milano, Sez. II, 11 giugno 2014 n. 1542, in www.giustizia-amministrativa.it.; TAR Veneto, Sez. I, 19.5.2009 n. 1504, in www.giustizia-amministrativa.it.

${ }^{34}$ STELLA RICHTER, 2014, p. 85.

${ }^{35}$ Ver em particular P. URBANI (2011, pp. 190-191).

${ }^{36}$ Conselho de Estado, Sez. IV, 13 julho 2010 n. 4545, in www.giustizia-amministrativa.it; TAR Emília

Romana, Bolohna, Sez. I, 9.3.2015 n. 224, em www.giustizia-amministrativa.it.

${ }^{37}$ TC, acordão 14 de Junho 2011 n. 190, em www.cortecostituzionale.it; URBANI, 2011, p. 191.

${ }^{38}$ TC, acordão 26 de Março de 2010 n. 121, em www.cortecostituzionale.it. 


\begin{abstract}
${ }^{39}$ A este respeito, deve-se, de qualquer modo, sublinhar que atualmente, a disciplina relativa à transferência de direitos de construção é referida no artigo $5^{\circ}$ do Decreto Legislativo ${ }^{\circ} 70 / 2011$ que, acrescentando o número 2 bis ao artigo 2643 do código civil, prevê literalmente que devem tornar-se público por transcrição "Os contratos que constituem, transferem ou modificam os direitos de construção, qualquer que seja sua denominação, previstos por regulamentos estatais ou regionais, ou por instrumentos de ordenamento territorial".

${ }^{40}$ Trata-se de instrumentos criados em áreas rurais ou urbanas por regiões ou municípios (Região da Galiça, Municipio de Cascais, entre outros) para registar as propriedades e o uso de terrenos em forma dinâmica ( e rapidamente atualizável) com o duplo objetivo de evitar o abandono e disponibilizá-los para todos aqueles que deles precisem para usos diferenciados (também temporários), e especialmente para usos de interesse social. A principal função dos Bancos de Terras é a de dinamizar políticas de interesse social e coletivo, e mediar entre os proprietários de terras e aqueles que precisam delas, oferecendo garantias, confiança e segurança na gestão e uso (e assim facilitando a obtenção de financiamentos diversos para conduzir as ditas atividades).
\end{abstract}

Trabalho enviado em 03 de abril de 2020

Aceito em 08 de maio de 2020 